Abd El-Aziz S. Fouda*1, Safaa Eldin H. Etaiw ${ }^{2}$, Essam El-Waseef ${ }^{1}$

${ }^{1}$ Mansoura University, Department of Chemistry, Faculty of Science, Mansoura, Egypt, ${ }^{2}$ Tanta University, Department of Chemistry, Faculty of Science, Tanta, Egypt
Scentific paper

ISSN 0351-9465, E-ISSN 2466-2585

UDC:665.7.038.5:532.74:542.913:669

https://doi.org/10.5937/zasmat2104316F

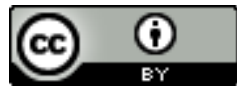

Zastita Materijala $62(4)$

$316-332(2021)$

\title{
Synthesis of two supramolecular coordination polymers and electrochemical evaluation of their corrosion inhibition performance on corrosion of Carbon Steel in Acidic medium
}

\begin{abstract}
The effect of the SCPs-[Cu'(en $\left.\left.)_{2}\right]\left[\mathrm{Cu}^{\prime}(\mathrm{CN})_{2}\right]_{2} \cdot \mathrm{H}_{2} \mathrm{O}\right](\mathrm{SCP} 1)$ and $\left\{\left[\mathrm{H}_{2} \mathrm{DAB}\right]\left[\mathrm{Cu}_{4}(\mathrm{CN})_{6}\right] \cdot 2 \mathrm{H}_{2} \mathrm{O}\right\}$ (SCP2) as corrosion inhibitors for carbon steel (CS) was studied in $1.0 \mathrm{M} \mathrm{HCl}$ solution. As the synthesized inhibitor dose increases, the inhibition productivity $(\% \eta)$ increases reaching to $90.3 \%$ and $89.9 \%$ at $21 \times 10^{-6} \mathrm{M}$ dose for SCP2 and SCP1, respectively. This result evidenced by mass loss (ML) investigated at three different temperatures $25-35-45^{\circ} \mathrm{C}$, while potentiodynamic polarization (PP), electrochemical impedance spectroscopy (EIS), and electrochemical frequency modulation technique (EFM) were tested at $25^{\circ} \mathrm{C}$. The synthesized inhibitors adsorbed on the CS surface physically allowing Henry isotherm. The results displayed that the synthesized inhibitors are excellent and their $(\% \eta)$ was significantly increased by raising the dose and decreased by raising the temperature. Polarization curves revealed that the synthesized inhibitors act as mixed type. The thermodynamic parameters were calculated and discussed. The protection was confirmed by the creation of the thin film of inhibitors precipitated on the surface of CS.
\end{abstract}

Keywords: Supramolecular coordination polymers, acid corrosion, carbon steel, Henry isotherm, EIS.

\section{INTRODUCTION}

Man has identified steel manufacturing as costeffective and vital as it is caused by one of the most industrial resistant issues [1]. Several factors influence its various applications, including its inexpensive cost, high energy density, and electrical capacity. In the presence of aggressive media such as $\mathrm{HCl}$, carbon steel is damaged, and corrosion of the metal begins [2]. Many acidic solutions, such as $\mathrm{HCl}, \mathrm{H}_{2} \mathrm{SO}_{4}$, and $\mathrm{HNO}_{3}$, are widely employed in a variety of procedures, including metal pickling, boiler cleaning, oil well acidification, and ion exchanger recovery. $\mathrm{HCl}$ is one of the acids that is commonly used to increase the productivity (stimulation) of wells in the oil and gas industry [3-6].

\footnotetext{
${ }^{*}$ Corresponding author: Abd El-Aziz S. Fouda

E-mail: asfouda@hotmail.com;

Paper received: 03. 08. 2021.

Paper corrected: 27. 09. 2021.

Paper accepted: 06. 10. 2021.
}

Paper is available on the website: www.idk.org.rs/journal
Corrosion inhibitors are chemicals that, when added in tiny amounts to corrosion solutions, can decrease or prevent metal contact with these solutions. Corrosion inhibitors have a wide range of applications. Inhibitors are organic compounds that contain heteroatoms such as nitrogen, oxygen, and sulphur atoms in addition to the numerous existing bonds, all of which aid in surface adsorption[7-10]. Later, obtaining synthetic organic inhibitors is lowcost in addition to being ecologically benign, accessible, and affordable, using renewable sources [11,12]. Many studies have been conducted to explore the inhibition of CS dissolving in acid environments using various types of synthetic composites [13], and organic composites have been used for mild steel corrosion prevention [14]. Aluminum [15], copper [16], and stainless steel [17-21] are examples of metals. Inorganic compounds also demonstrated the greatest corrosion resistance for a variety of metals [22]. The use of MOF to improve the anticorrosive characteristics of epoxy coatings has been documented in the literature [23]. In 2017 [24,25], 
the influence of $\mathrm{Co}, \mathrm{Ni}$, and $\mathrm{Cu}$ based MOFs on mild steel corrosion prevention was reported [26]. According to Fouda et al, a 3D network of silverbased MOF proved adequate for preventing corrosion of carbon steel in $1 \mathrm{M} \mathrm{HCl}$. Another research found that MOFs with both $\mathrm{Ag}$ and $\mathrm{N}$ donors were effective corrosion inhibitors for $\mathrm{Cu}$ in $\mathrm{HCl}$ solution [27]. In $\mathrm{HCl}$ media, a new MOF called Zeolite imidazolate framework nano structure was described as a corrosion inhibitor for carbon steel [28]. A great deal of research is being conducted in order to develop low-cost, environmentally safe, and highly effective inhibitors. Because of the proximity of a metal ion and an organic framework, the MOF appears to be a sustainable inhibitor. Metals that are more electropositive, such as $\mathrm{Zn}$ and $\mathrm{Mg}$, can shield the Fe articles. The proximity of a more electropositive metal in an organic system enhances hindrance efficacy. In this paper, the effect of the two supramolecular coordination polymers as corrosion inhibitors for C-steel in 1.0M $\mathrm{HCl}$ were studied. In this research, several methods have been used to study the inhibition behavior, including electrochemical and chemical studies.

\section{EXPERIMENTAL}

\subsection{Materials and solutions}

The CS used in this study had the chemical conformation (wt \%), Mn 0.6, P 0.04, Si 0.003, and iron rest. The corrosive environment, $1.0 \mathrm{M} \mathrm{HCl}$ was ready by dilution of analytical grade $(37 \%) \mathrm{HCl}$ with double distilled water. The dose range of the inhibitors utilized was $1-21 \times 10^{-6} \mathrm{M}$.

$\mathrm{K}_{3}\left[\mathrm{Cu}(\mathrm{CN})_{4}\right], \mathrm{Me}_{3} \mathrm{Sn} \mathrm{Cl}$, ethylenediamine, 1,4diaminobutane, all BDH grade and purcushed from Al-Gomhoria company, Egypt

$$
\begin{aligned}
& \mathrm{K}_{3}\left[\mathrm{Cu}(\mathrm{CN})_{4}\right]+\mathrm{Me}_{3} \mathrm{SnCl}+\mathrm{NH}_{2} \mathrm{CH}_{2} \mathrm{CH}_{2} \mathrm{NH}_{2} \longrightarrow\left[\mathrm{Cu}^{\prime \prime}(\mathrm{en})_{2}\right] \cdot\left[\mathrm{Cu}(\mathrm{CN})_{2}\right]_{2} \cdot \mathrm{H}_{2} \mathrm{O} \\
& \text { SCP1 }
\end{aligned}
$$

$$
\mathrm{K}_{3}\left[\mathrm{Cu}(\mathrm{CN})_{4}\right]+\mathrm{Me}_{3} \mathrm{Sn} \mathrm{Cl}+\mathrm{NH}_{2}\left(\mathrm{CH}_{2}\right)_{4} \mathrm{NH}_{2} \stackrel{\text { Acetonitrile/ } / \mathrm{H}_{2} \mathrm{O}}{\longrightarrow} \nabla\left[\mathrm{H}_{2} \mathrm{DAB}\right]\left[\mathrm{Cu}_{4}(\mathrm{CN})_{6}\right] \cdot 2 \mathrm{H}_{2} \mathrm{O}
$$

\section{SCP2}

Table 1. Elemental analysis data of SCP1 and SCP2

Tabela 1. Podaci o elementarnoj analizi SCP1 i SCP2

\begin{tabular}{|c|c|c|c|c|c|c|c|c|c|}
\hline \multirow{2}{*}{ Comp. } & \multicolumn{4}{|c|}{ Calcd. Values } & \multicolumn{4}{c|}{ Found values } \\
\cline { 2 - 10 } & $\mathrm{Mol} . \mathrm{Wt}$ & $\mathrm{C}$ & $\mathrm{H}$ & $\mathrm{N}$ & $\mathrm{Cu}$ & $\mathrm{C}$ & $\mathrm{H}$ & $\mathrm{N}$ & $\mathrm{Cu}$ \\
\hline SCP1 & $\begin{array}{c}\left.\mathrm{C}_{10} \mathrm{H}_{18} \mathrm{~N}_{8} \mathrm{O}_{2} \mathrm{Cu}_{4}\right) \\
\mathrm{M} . \mathrm{W} .=536.492 \mathrm{~mol}^{-1}\end{array}$ & 22.36 & 3.38 & 20.89 & 47.38 & 22.30 & 3.39 & 20.82 & 47.40 \\
\hline SCP2 & $\begin{array}{c}\left(\mathrm{C}_{8} \mathrm{H}_{18} \mathrm{~N}_{8} \mathrm{OCu}_{3}\right) \mathrm{M} . \mathrm{W} .=432.9 \\
\mathrm{~g} \mathrm{~mol}^{-1}\end{array}$ & 22.17 & 4.15 & 25.87 & 44.04 & 22.10 & 4.09 & 25.77 & 43.95 \\
\hline
\end{tabular}




\subsection{Methods}

\subsubsection{Chemical measurements}

\subsubsection{Mass Loss (ML) Measurements}

The seven coins are cut then washed with double distilled water, dried, weighed and put them in solutions prepared from different doses of synthetic compounds (SCP1 \&SCP2) from 1 to $21 \times 10^{-6} \mathrm{M}$. This occurs in the presence of $1.0 \mathrm{M}$ hydrochloric acid to compare with a sample that was putted in a solution of $1.0 \mathrm{M} \mathrm{HCl}$ without any adding. Coins are left for half an hour in solutions. Then, they were collected and dried, weighed, and then placed again in their solutions. The steps are repetitive till the end of the experiment after 3 hours. Experiments were taken in triplicate to get best reproducibility. The beakers $100 \mathrm{ml}$ were utilized for ML tests. Each time ML is measured and drawn. The temperature range is from 25 to $45^{\circ} \mathrm{C}$.

\subsubsection{Electrochemical measurements}

2.3.2.1 Potentiodynamic (PP) investigation technique: was utilized through a cell consisting of three electrodes, which is the working electrode that is studied as before [29,30]. This electrode consists of CS metal, where the method of preparation was explained previously [31], and the surface area exposed in it is $1 \mathrm{~cm}^{2}$ and before using the electrode it is processed according to the test followed $M L$, the reference electrode is saturated calomel electrode (SCE) and the auxiliary electrode ( $\mathrm{Pt}$ foil) is the last. For the CS electrode, it is engaged in the solution utilized at the OCP for 30 minutes, where the stability condition is obtained. PP diagrams were verified at a steady scan rate of $1 \mathrm{mVs}^{-1}$ initially from -600 to $600 \mathrm{mV}$ (SCE). In this test, the current density is utilized for the measurements [32,33].
2.3.2.2. Electrochemical impedance spectroscopy (EIS) test: was performed by using AC signals ranging from $100 \mathrm{kHz}$ to $0.1 \mathrm{~Hz}$ with an amplitude of peaks $10 \mathrm{mV}$ at OCP. The same cell previously used in PP test was used in EIS test. All the results of impedance using the charge transfer resistance were utilized to calculate $(\% \eta)$.

2.3.2.3 Electrochemical frequency modulation (EFM) test: was investigated applying the signal with a capacity of $10 \mathrm{mV}$ through two sinus waves from 2 to $5 \mathrm{~Hz}$ [34]. This technology is fast and not destructive. Corrosion current density ( $\left.\mathrm{i}_{\text {corr }}\right)$, causal factors CF2 and CF3, and Tafel slopes $\left(\beta_{a} \& \beta_{c}\right)$ were determined through the higher peaks [35]. In electrochemical investigations, the device used was Gamry Potentiostat / Galvanostat / ZRA (PCl4G750). Gamry includes DC105 DC Corrosion Program and EIS300 EIS program, the EFM140 for EFM program, as well as a computer for data collection. Echem Analyst version 5.5 was used to plot, calculate, and synthesize data. All electrochemical studies were applied at $25^{\circ} \mathrm{C}$.

\section{RESULTS AND DISCUSSION}

\subsection{Crystal Structure of $\left[\mathrm{Cu}^{\prime \prime}(\mathrm{en})_{2} \cdot \mathrm{H}_{2} \mathrm{O}\right]\left[\mathrm{Cu}^{\prime}(\mathrm{CN})_{2}\right]_{2}$, SCP1}

Violet prismatic crystals of [Cull(en $)_{2} \cdot \mathrm{H}_{2} \mathrm{O}$ ] $\left.\left[\mathrm{Cul}(\mathrm{CN})_{2}\right]_{2}\right]$ are organotin-free. The ternary adducts $\mathrm{K}_{3}\left[\mathrm{Cu}(\mathrm{CN})_{4}\right], \quad \mathrm{Me}_{3} \mathrm{SnCl}$ and ethylenediamine (en) react to produce SCP1 $[36,37]$. So far, all attempts to produce crystals containing the organotin adduct have resulted in SCP1. SCP1 crystallises in the monoclinic space group $\mathrm{Cc}, \mathrm{Z}=$ 4, as shown in Table 2. SCP1 has an asymmetric unit. The asymmetric unit of SCP1 is made up of two copper (I) sites linked by four cyanide groups, as shown in Figure 1.

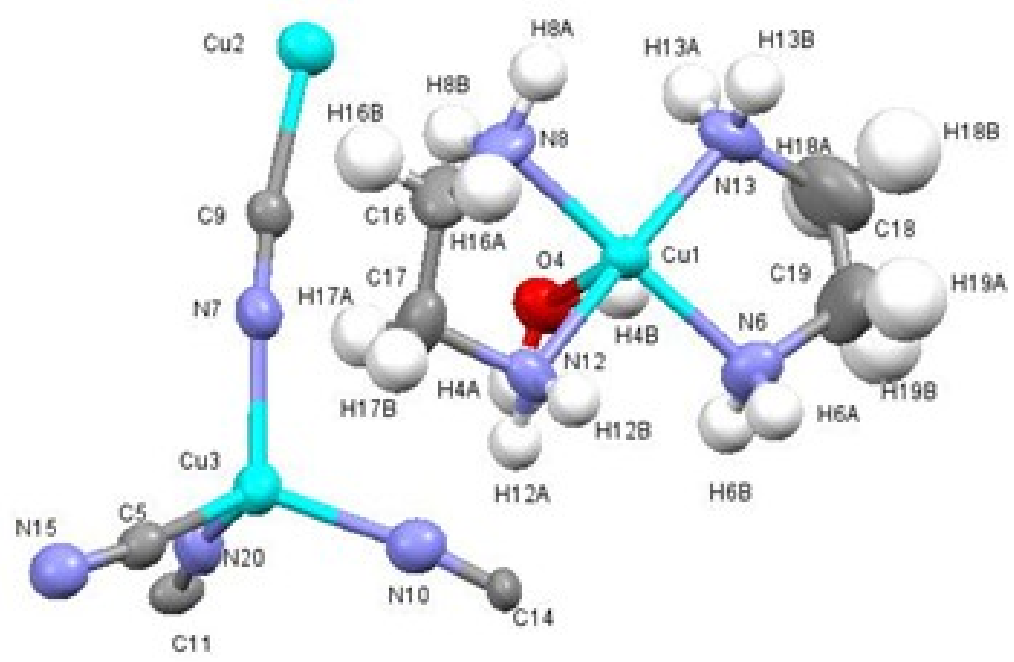

Figure 1. ORTEP plot of the asymmetric unit of SCP1

Slika 1. ORTEP dijagram asimetrične jedinice SCP1 
Table 2. Crystal data and structure refinement parameters for SCP2 and SCP1

Tabela 2. Kristalni podaci i parametri preciziranja strukture za SCP2 i SCP1

\begin{tabular}{|c|c|c|}
\hline & $\begin{array}{c}\mathrm{SCP} 2(\mathrm{~A}) \\
{[\mathrm{H} 2 \mathrm{DAB}]\left\{\left[\mathrm{Cu}_{4}(\mathrm{CN})_{6}\right] .2 \mathrm{H} 2 \mathrm{O}\right\}}\end{array}$ & $\begin{array}{c}\mathrm{SCP} 1(\mathrm{~B}) \\
\left.[\mathrm{Cu} I \mathrm{en})_{2}\right]\left[\mathrm{Cu}_{1}(\mathrm{CN})_{2}\right]_{2} . \mathrm{H}_{2} \mathrm{O}\end{array}$ \\
\hline Empirical formula & $\mathrm{C}_{10} \mathrm{H}_{18} \mathrm{O}_{2} \mathrm{~N}_{8} \mathrm{Cu}_{4}$ & $\mathrm{C}_{8} \mathrm{H}_{18} \mathrm{~N}_{8} \mathrm{OCu}_{3}$ \\
\hline Formula weight & 536.492 & 432.925 \\
\hline Temperature & $298^{\circ} \mathrm{K}$ & $298^{\circ} \mathrm{K}$ \\
\hline Wavelength & $0.71073 \AA$ & $0.71073 \AA$ \\
\hline Crystal system, space group & Monoclinic, P 21/c & Monoclinic, Cc \\
\hline Volume & $939.88(11) \AA^{3}$ & $1513.50(7) \AA^{3}$ \\
\hline Z, calculated density & $2,1.896 \mathrm{Mg} / \mathrm{mm}^{3}$ & $4,1.900 \mathrm{Mg} / \mathrm{mm}^{3}$ \\
\hline Absorption coefficient & $4.48 \mathrm{~mm}^{-1}$ & $4.19 \mathrm{~mm}^{-1}$ \\
\hline$F(000)$ & 532 & 844 \\
\hline Theta range for data collection & 2.910 to $27.485 \mathrm{deg}$. & 2.910 to $27.485 \mathrm{deg}$. \\
\hline Limiting indices & $0<=\mathrm{h}<=9,0<=\mathrm{k}<=11,-21<=\mid<=18$ & $0<=h<=19,0<=k<=10,-18<=\mid<=16$ \\
\hline $\mathrm{R}$ (int) & 0.032 & 0.027 \\
\hline Absorption correction & None & None \\
\hline Refinement test & Full-matrix least-squares on $\mathrm{F}^{2}$ & Full-matrix least-squares on $\mathrm{F}^{2}$ \\
\hline Data / restraints / parameters & $929 / 0 / 109$ & $1160 / 0 / 181$ \\
\hline Goodness-of-fit on $\mathrm{F}^{2}$ & 1.743 & 2.464 \\
\hline Final $r$ indices $[\mathrm{l}>2$ sigma $(\mathrm{l})]$ & $R 1=0.042, w R 2=0.083$ & $R 1=0.04, w R 2=0.120$ \\
\hline $\mathrm{R}$ indices (all data) & $\mathrm{R} 1=0.093, w R 2=0.109$ & $\mathrm{R} 1=0.073, \mathrm{wR} 2=0.126$ \\
\hline Largest diff. peak and hole & 0.82 and -0.84 e. $\AA^{-3}$ & 0.96 and -1.19 e. $\AA^{-3}$ \\
\hline
\end{tabular}

Each copper (I) site has distorted tetrahedral geometry, creating a 3D network, Table $3 \mathrm{a}$, with an adamantanoid-shaped structure with six-membered rings, $\mathrm{Cu}_{6}(\mathrm{CN})_{6}$, including large gaps; ca. $10.433 \AA$; capable of encapsulating the guest [Cull $\left.(e n)_{2} \mathrm{H}_{2} \mathrm{O}\right]$ complex, Figure 2.

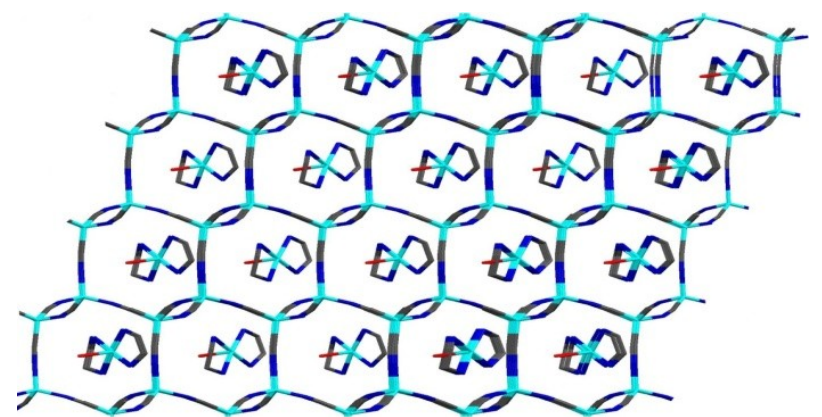

Figure 2. View of the overall 3D-network of 1 showing the encapsulation of the cationic

$$
\mathrm{Cu}^{\prime \prime}(\mathrm{en}) \mathrm{H}_{2} \mathrm{O} \text { unit }
$$

Slika 2. Prikaz ukupne 3D mreže 1 koja prikazuje inkapsulaciju katjonske $\mathrm{Cu}^{\prime \prime}$ (en) $\mathrm{H}_{2} \mathrm{O}$

\subsection{Crystal Structure of $\left\{\left[\mathrm{H}_{2} D A B\right]\right.$}

$\left.\left[\mathrm{Cu}_{4}(\mathrm{CN})_{6}\right] \cdot 2 \mathrm{H}_{2} \mathrm{O}\right\}, \mathrm{SCP} 2$

The 3D-SCP, $\left[\mathrm{H}_{2} \mathrm{DAB}\right] \quad\left[\mathrm{Cu}_{4}(\mathrm{CN})_{6}\right] \cdot 2 \mathrm{H}_{2} \mathrm{O}, 2$ crystallises in space group $\mathrm{P} 21 / \mathrm{C}$ with unit cell dimensions of $a=7.4307 \AA, b=8.6193 \AA$, $c=$ $16.4489 \AA$, and $Z=2$. Table No. 2 The asymmetric unit is made up of a $\left[\mathrm{Cu}_{2}(\mathrm{CN})_{3}\right]$ unit, half a molecule of $\mathrm{H}_{2} \mathrm{DAB}$, and one water molecule, as shown in Figure 3. SCP2 is made up of $\mathrm{Cu} C N$ endless zig-zag chains linked by 2-cyanide bridges.

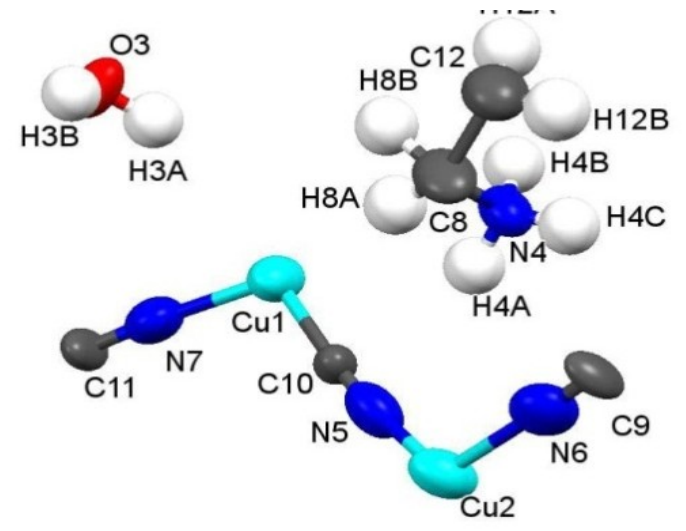

Figure 3. Asymmetric unit of SCP2 showing the atomic labeling scheme

\section{Slika 3. Asimetrična jedinica SCP2 koja prikazuje šemu atomskog obeležavanja}

These CuCN chains are linked to create puckered 2D-hexagonal sheets of $(\mathrm{CuCN})_{6}$ with all edges shared, as seen in Fig.4. Table $3 \mathrm{~b}$ shows how each copper (I) site is coordinated to three ordered cyanide groups, resulting in a deformed planar-trigonal shape. The negatively hexagonal sheets form parallel layers with large channels (Ca. $7.41 \AA$ ) capable of encapsulating $\mathrm{H}_{2} \mathrm{DAB}$ cations 
and water molecules, as seen in Fig. 4. 3D-network structure was stabilised by hydrogen bonding (1.976-2.564 $\AA$ ), resulting in a honeycomb-like network.

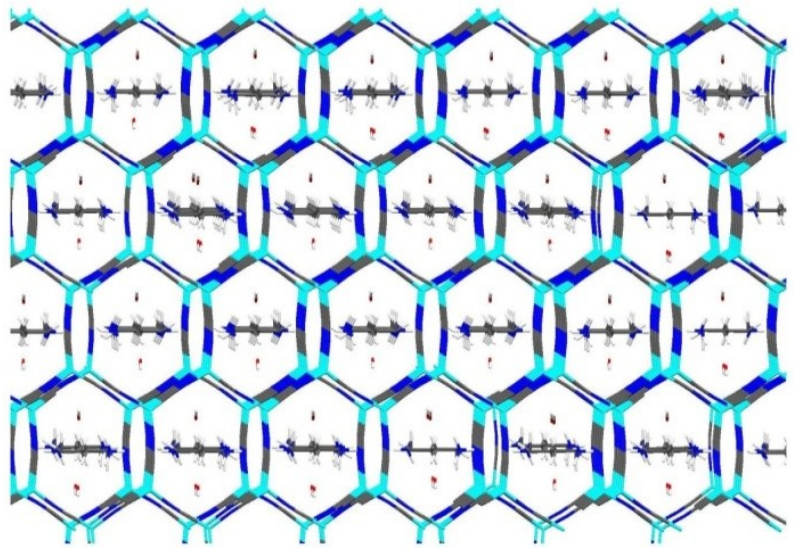

Figure 4. View of the $3 D$-struture of SCP2 along the a-axis showing the encapsulation of the organic ligand and water molecules in the cavities

Slika 4. Pogled na 3D-strukturu SCP2 duž a-ose koja prikazuje inkapsulaciju organskog liganda $i$ molekula vode $u$ šupljinama

Table 3a. Selected bond lengths $(\AA)$ and bond angles ( ${ }^{\circ}$ ) of SCP1

Tabela 3a. Odabrane dužine veze $(\AA)$ i uglovi veze () SCP1

\begin{tabular}{|c|c|c|c|c|}
\hline u1 & $\mathrm{O} 4$ & $2.463(3)$ & Cu1 N6 & $87.24(11)$ \\
\hline Cu1 & N6 & $2.008(3)$ & Cu1 N8 & $96.11(10)$ \\
\hline Cu1 & N8 & $1.982(3)$ & Cu1 N12 & 95.46(9) \\
\hline Cu1 & N12 & $2.035(3)$ & Cu1 N13 & $93.68(10)$ \\
\hline Cu1 & N13 & $1.995(3)$ & Cu1 N8 & 176.62(13) \\
\hline $\mathrm{Cu} 2$ & $\mathrm{C9}$ & $1.973(3)$ & Cu1 N12 & $95.14(12)$ \\
\hline $\mathrm{Cu} 2$ & C11 & $1.937(3)$ & Cu1 N13 & $84.52(14)$ \\
\hline $\mathrm{Cu} 2$ & C14 & $1.982(3)$ & Cu1 N12 & $84.11(13)$ \\
\hline Cu2 & N15 & $2.098(4)$ & Cu1 N13 & $95.68(15)$ \\
\hline Cu3 & C5 & $1.971(4)$ & N12 Cu1 N13 & $170.83(11)$ \\
\hline Cu3 & N7 & $2.007(3)$ & C9 Cu2 C11 & 113.32(14) \\
\hline Cu3 & N10 & $1.975(3)$ & C9 Cu2 C14 & $111.83(12)$ \\
\hline Cu3 & N20 & $2.042(4)$ & C9 $\mathrm{Cu} 2 \quad \mathrm{~N} 15$ & $105.25(13)$ \\
\hline C5 & N15 & $1.159(5)$ & C11 Cu2 C14 & $115.37(14)$ \\
\hline N6 & C19 & $1.429(7)$ & C11 Cu2 N15 & 102.52(15) \\
\hline N7 & $\mathrm{C9}$ & $1.163(4)$ & C14 Cu2 N15 & $107.40(13)$ \\
\hline N8 & C16 & $1.481(6)$ & Cu3 N7 & 111.95(14) \\
\hline N10 & C14 & $1.142(4)$ & C5 Cu3 N10 & $118.04(14)$ \\
\hline C11 & $\mathrm{N} 20$ & $1.165(5)$ & C5 Cu3 N20 & 104.86(15) \\
\hline N12 & C17 & $1.495(5)$ & N7 $\quad$ Cu3 N10 & $109.12(12)$ \\
\hline N13 & C18 & $1.462(7)$ & N7 Cu3 N20 & $104.70(13)$ \\
\hline C17 & C16 & $1.479(7)$ & N10 Cu3 N20 & $107.13(13)$ \\
\hline C18 & C19 & $1.336(9)$ & Cu3 C5 N15 & $166.7(3)$ \\
\hline \multicolumn{3}{|c|}{ Cu3 N7 C9 171.3(3) } & & \\
\hline
\end{tabular}

Table 3b. Selected bond lengths $(A)$ and bond angles ( 9 ) of SCP2

Tabela 3b. Odabrane dužine veze $(\AA)$ i uglovi veze ()) SCP2

\begin{tabular}{|c|c|c|c|}
\hline $\begin{array}{ll}\text { u1 } & \text { N7 }\end{array}$ & $1.949(5)$ & N7 Cu1 C10 & $116.6(2)$ \\
\hline Cu1 C11 & $1.884(4)$ & N7 Cu1 C11 & $121.6(2)$ \\
\hline Cu2 N6 & $1.942(5)$ & C10 Cu1 C11 & $121.0(2)$ \\
\hline N4 C8 & $1.483(6)$ & N5 $\mathrm{Cu} 2 \mathrm{N6}$ & $120.8(2)$ \\
\hline N5 $\mathrm{C} 10$ & $1.154(6)$ & N5 Cu2 C9 & (2) \\
\hline N7 C11 & $1.146(6)$ & N6 $\mathrm{Cu} 2 \mathrm{C} 9$ & $121.5(2)$ \\
\hline Cu1 N7 & 1.949 & C8 $\quad \mathrm{N} 4 \quad \mathrm{C} 12$ & 35.8 \\
\hline Cu1 C11 & $1.884(4)$ & Cu2 N5 C10 & $173.0(4)$ \\
\hline Cu2 N6 & $1.942(5)$ & Cu2 N6 C9 & $169.9(5)$ \\
\hline $\mathrm{N} 4 \mathrm{C} 8$ & $1.483(6)$ & Cu1 N7 C11 & $176.4(4)$ \\
\hline N5 C10 & $1.154(6)$ & N4 $\quad$ C8 $\quad$ C12 & $108.2(4)$ \\
\hline N7 C11 & $1.146(6)$ & Cu2 C9 N6 & $176.5(4)$ \\
\hline Cu1 C11 N7 & $170.5(5)$ & Cu1 C10 N5 & $174.1(3)$ \\
\hline N4 C12 C8 & $36.0(2)$ & & \\
\hline
\end{tabular}

\subsection{Measurements}

$\mathrm{ML}$ is one of the important methods in determining the efficiency of the inhibitor to inhibit the corrosion of CS the experiments were conducted on altered doses of the synthetic compounds in 1.0 molar hydrochloric acid. "Experiments were conducted at altered temperatures $\left(25-35-45^{\circ} \mathrm{C}\right)$. Table 4 shows the results obtained in a time of 120 minutes as an example of the study. The results showed that by increasing the doses from $1 \times 10^{-6} \mathrm{M}$ to $21 \times 10^{-6} \mathrm{M}$, the inhibition efficincy increases in contrast to the corrosion rate (C.R), which lowered with increasing doses of inhibitors. By increasing the temperature, the $\% \eta_{M L}$ broke down, while the C.R (Figure 5) for synthetic inhibitor SCP1 rises, similar curves gotten from another synthetic inhibitor SCP2 235 (not display). The increased \% $\eta_{M L}$ with raised dose of synthetic inhibitors can be qualified to the creation of a layer of the inhibitors on the CS surface by adsorption. This layer is formed by the pairs of free electrons present on the oxygen and nitrogen atoms in the inhibitor molecules as well as the $\pi$-electrons of the aromatic rings". Decrease in the \% $\eta_{M L}$ with a higher temperature may likely be due to an increased rate of desorption meaning that is physical adsorption. The degree of coverage of CS surface $(\theta)$ and the $(\% \eta)$ were measured utilizing the next eq.:

$$
\% \eta_{M L}=\theta \times 100=\left[1-\left(\Delta W_{u} / \Delta W_{i}\right)\right] \times 10
$$

where $\Delta W_{u}$ and $\Delta W_{i}$ are the $M L$ per unit area of uninhibited and inhabited solution, correspondingly. The data of C.R and \% $\eta$ were gotten from synthetic compounds at altered doses and temperature are summarized in Table (4). 


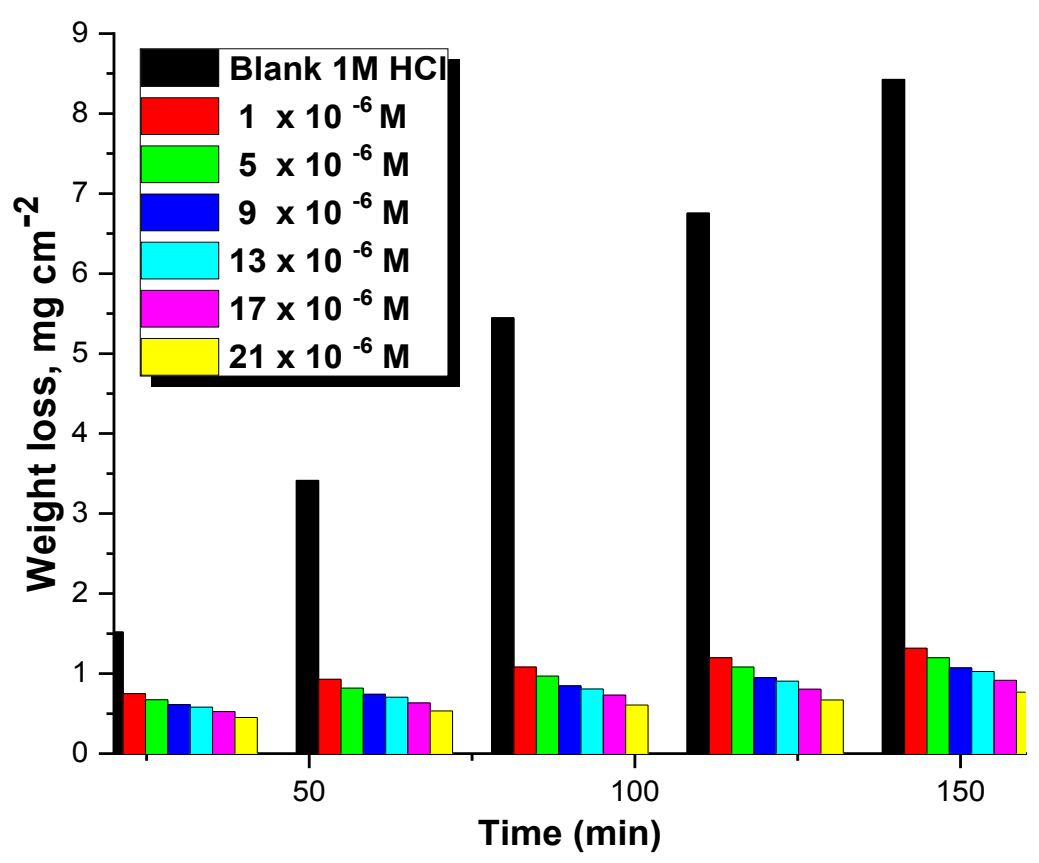

Figure 5. ML-time diagrams for the dissolution of CS absence and presence altered doses of compound SCP1 at $25^{\circ} \mathrm{C}$

Slika 5. ML-vremenski dijagrami za rastvaranje CS odsustva i prisustva izmenjenih doza jedinjenja SCP1 na $25^{\circ} \mathrm{C}$

Table 4. Outcome data of ML of CS in $1.0 \mathrm{M} \mathrm{HCl}$ for various doses of synthetic inhibitors after 120 min. at $\left(25,35,45^{\circ} \mathrm{C}\right)$

Tabela 4. Podaci o ishodu ML CS u $1.0 \mathrm{M} \mathrm{HCl}$ za različite doze sintetičkih inhibitora nakon 120 min. na $\left(25,35,45^{\circ} \mathrm{C}\right)$

\begin{tabular}{|c|c|c|c|c|c|}
\hline \multirow[b]{2}{*}{ Temp., ${ }^{\circ} \mathrm{C}$} & \multirow{2}{*}{$\begin{array}{l}\text { Conc., } \\
\times 10^{-6} \mathrm{M}\end{array}$} & \multicolumn{2}{|c|}{ SCP2 } & \multicolumn{2}{|c|}{ SCP1 } \\
\hline & & $\begin{array}{c}\text { C.R. } \times 10^{2} \\
\mathrm{mg} \mathrm{cm}^{-2} \mathrm{~min}^{-1}\end{array}$ & $\% \eta_{M L}$ & $\begin{array}{c}\text { C.R. x } 10^{2} \\
\mathrm{mg} \mathrm{cm}^{-2} \mathrm{~min}^{-1}\end{array}$ & $\% \eta_{M L}$ \\
\hline \multirow{6}{*}{25} & 1 & 1.00 & 82.2 & 1.16 & 79.3 \\
\hline & 5 & 0.90 & 84.0 & 1.07 & 81.1 \\
\hline & 9 & 0.79 & 85.9 & 0.96 & 83.0 \\
\hline & 13 & 0.75 & 86.6 & 0.92 & 83.7 \\
\hline & 17 & 0.67 & 88.1 & 0.84 & 85.2 \\
\hline & 21 & 0.56 & 90.1 & 0.72 & 87.2 \\
\hline \multirow{6}{*}{35} & 1 & 1.43 & 76.2 & 1.59 & 73.4 \\
\hline & 5 & 1.30 & 78.3 & 1.47 & 75.5 \\
\hline & 9 & 1.06 & 82.3 & 1.23 & 79.5 \\
\hline & 13 & 0.99 & 83.5 & 1.16 & 80.7 \\
\hline & 17 & 0.91 & 84.9 & 1.07 & 82.1 \\
\hline & 21 & 0.78 & 87.0 & 0.95 & 84.2 \\
\hline \multirow{6}{*}{45} & 1 & 3.44 & 71.8 & 3.61 & 70.4 \\
\hline & 5 & 3.15 & 74.2 & 3.32 & 72.7 \\
\hline & 9 & 2.77 & 77.3 & 2.94 & 75.9 \\
\hline & 13 & 2.56 & 79.0 & 2.73 & 77.6 \\
\hline & 17 & 2.18 & 82.1 & 2.35 & 80.7 \\
\hline & 21 & 1.83 & 85.0 & 2.01 & 83.5 \\
\hline
\end{tabular}




\subsection{Adsorption Isotherm Behavior}

The nature of corrosion inhibition has been deduced in terms of the adsorption characteristics of the inhibitors. The outcome data gotten from synthetic compounds designate that the corrosion protection was caused by the components of synthetic composite tending to interact and adsorb on the interface among CS / solution. One or more of the three main types of adsorptions can occur: $\pi$ bonding, chemical and physical adsorption [38] The adsorption process increases if the inhibitor compounds contain hetero- atoms such as nitrogen, sulfur, and oxygen where these atoms give one pair of electrons which leads to electrostatic adsorption on the surface of CS creating an insoluble layer which reduces the dissolution of CS. Through appropriate isothermal process, adsorption situation of synthetic compound can be detected on the CS surface. At various temperatures, data for $\mathrm{ML}$ tests was utilized, and they were prepared in various mathematical adsorption isotherm expressions to identify the more suitable adsorption isotherms". From this research for altered adsorption isotherms the more suitable adsorption isotherms for synthetic compounds were Henry isotherms Figure 6. According to this isotherm, the $\theta$ is related to inhibitor dose by:

$$
\theta=K C
$$

The symbols in these equations $\mathrm{C}, \mathrm{K}_{\text {ads }}$ express on the dose of synthetic compound and equilibrium constant of adsorption process, correspondingly. "The investigative the data in Table 5, the value of $\mathrm{R}^{2}$ for the Henry isotherm was more exactly closer to the unit. So, Henry adsorption isotherm was known to be the excellent explanation of the inhibitor adsorption behavior studied on the surface of CS. In Table 5, the symbol $\mathrm{K}_{\mathrm{ads}}$ shows the molecular strength of the adsorbed layer and indicates the strength of adsorption. Small values of $\mathrm{K}_{\mathrm{ads}}$, however, reveal that such interactions between adsorbing inhibitor molecules and the metal surface are weaker", indicating that the inhibitor molecules are easily removable by the solvent molecules from the metal surface.

In current study, free energy was used to study the interaction of synthetic compounds (1\&2) molecules, and this was done using the following formula:

$$
\Delta G^{0}{ }_{a d s}=-R T \ln \left(55.5 x K_{a d s}\right)
$$

In this equation the value 55.5 reveals the water concentration in the bulk solution where it is expressed in $\mathrm{mol} / \mathrm{L}$ [39]. Table 5 shows the adsorption parameters for the obtained synthetic compounds. The data of the table confirm the spontaneous adsorption of synthetic compounds on the CS surface, through the negative values obtained free energy. From literature survey, the results obtained from $\Delta \mathrm{G}^{0}$ ads confirm that the kind of adsorption lead to physical adsorption as it is known when they are less than $20 \mathrm{~kJ} / \mathrm{mol}$ are physisorption and this resembles to the data obtained [34]. Vant't Hoff equation can be used to measure $\Delta \mathrm{H}^{\circ}$ ads and $\Delta \mathrm{S}^{\circ}$ ads expressed by:

$$
\text { Ln } K_{a d s}=\frac{-\Delta H^{\circ}{ }_{a d s}}{R T}+\text { const }
$$

Figure 7 demonstrations the relation among log $\mathrm{K}_{\mathrm{ads}}$ and $1 / \mathrm{T}$, the change of the standard adsorption enthalpy was determined $\left(-\Delta \mathrm{H}^{0}\right.$ ads $)$ and the entropy value was specified $\left(-\Delta S^{0}\right.$ ads $)$ calculated from next balance:

$$
\Delta G^{o}{ }_{\text {ads }}=\Delta H^{\circ} \text { ads }-T \Delta S^{o} \text { ads }
$$

In the current research, we know that the data of enthalpy is negative, which means that adsorption molecules of synthetic inhibitors are exothermic. The exothermic process can refer to physical or chemical adsorption, but the $\Delta H^{0}$ ads are less than $100 \mathrm{~kJ} / \mathrm{mol}$, representing that the adsorption is chiefly physical adsorption [40].

Table 5. Parameters of Henry adsorption for adsorption of investigated polymers on the CS surface at altered temperatures

Tabela 5. Parametri Henrijeve adsorpcije za adsorpciju ispitivanih polimera na površini CS na promenjenim temperaturama

\begin{tabular}{|c|c|c|c|c|c|}
\hline \multirow{2}{*}{ Comp. } & \multirow{2}{*}{ Temp. ${ }^{\circ} \mathrm{C}$} & \multicolumn{4}{|c|}{ Adsorption parameter } \\
\cline { 2 - 4 } & & $\mathrm{K}_{\mathrm{ads}, \mathrm{M}^{-1}}$ & $-\Delta \mathrm{G}_{\mathrm{ads}}^{\circ}, \mathrm{kJ} \mathrm{mol}^{-1}$ & $-\Delta \mathrm{H}_{\mathrm{ads}}^{\circ} \mathrm{kJ} \mathrm{mol}^{-1}$ & $-\Delta \mathrm{S}_{\mathrm{ads}}^{\circ} \mathrm{J} \mathrm{mol}^{-1} \mathrm{~K}^{-1}$ \\
\hline \multirow{3}{*}{ SCP2 } & 25 & 3.8 & 13.2 & \multirow{2}{*}{22} & 44 \\
\cline { 2 - 4 } & 35 & 5.4 & 14.6 & & 47 \\
\cline { 2 - 4 } & 45 & 6.5 & 15.6 & & 49 \\
\hline \multirow{3}{*}{ SCP1 } & 25 & 3.3 & 12.9 & \multirow{2}{*}{21} & 43 \\
\cline { 2 - 4 } & 35 & 4.8 & 14.3 & 46 \\
\cline { 2 - 4 } & 45 & 5.7 & 15.3 & & 48 \\
\hline
\end{tabular}




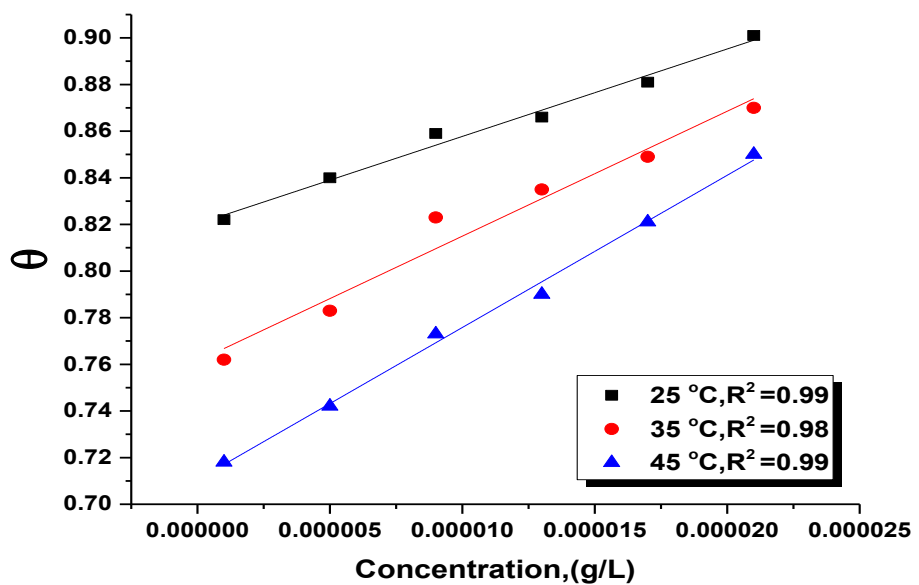

Figure 6. Plots as $(\theta)$ vs. $C$ of the synthetic compounds for dissolution of $C S$ in $1.0 \mathrm{M} \mathrm{HCl}$ solution from $M L$ tests at $25^{\circ} \mathrm{C}$

Slika 6. Krive $(\theta)$ u odnosu na $C$ sintetičkih jedinjenja za rastvaranje $C S$ u $1,0 \mathrm{M} \mathrm{HCl}$ iz $\mathrm{ML}$ testova na $25^{\circ} \mathrm{C}$

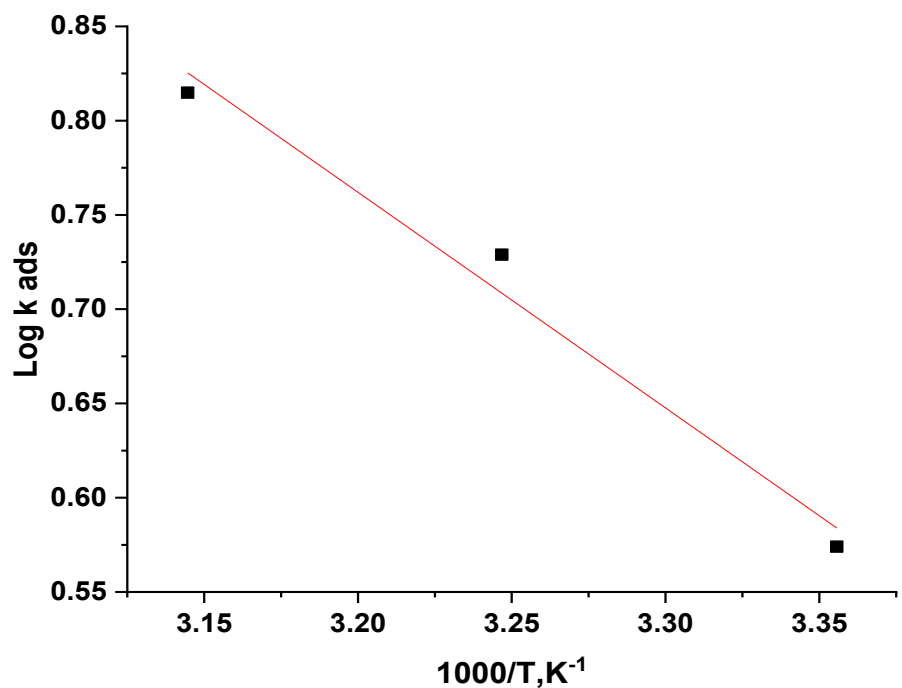

Figure 7. (log $\left.K_{\text {ads }}\right)$ vs. (1/T) for the liquefaction of CS in $1.0 \mathrm{M} \mathrm{HCl}$ in the existence of compound SCP2

Slika 7. (log $\left.K_{a d s}\right)$ vs. (1/T) za ukapljivanje CS u 1,0M HCl u postojanju jedinjenja SCP2

\subsection{Effect of Temperature}

In this examination, the effect of temperature on the dissolution of CS coins utilized in the synthetic compounds and dipped in $1.0 \mathrm{M}$ of hydrochloric acid was studied in the presence and absence of altered doses of synthetic compounds $\left(1 \times 10^{-6}-21 \times 10^{-6} \mathrm{M}\right)$ at $25-35-45^{\circ} \mathrm{C}$. "It has been found that the C.R rises with raising temperatures. The activation energy $\left(E^{*}\right)$ measured from the slope of the diagrams utilized the Arrhenius eq. (6) was used [41],

$$
\log C . R .=\log A-E_{a}^{*} / 2.303 R T
$$

while the symbol (A) was utilized for the term exponential factor of Arrhenius. Arrhenius diagrams are illustrated in Figure 8 [log (C.R) against 1/T], in which the energy of the activation is derived from the slopes of straight lines $\left[-E^{*} / 2.303 R\right]$. Using the transitional state equation, the changes in entropy and enthalpy were calculated [42]

$\log (C . R / T)=\left[\log (R / N h)+\Delta S^{*} / 2.303 R\right]-\Delta H_{a}^{*} / 2.303 R T$

Figure 9 shows a plotting log (C.R/T) against $1000 / T$, where this Figure shows the transitional state of the synthetic compound. Slopes are utilized to calculate enthalpy $\left(\left(-\Delta \mathrm{H}^{*}{ }_{\mathrm{a}} / 2.303 \mathrm{R}\right)\right.$, and the activation entropy of the process is calculated utilizing intersections of the $\operatorname{lines}[\log (\mathrm{R} / \mathrm{Nh})$ $\left.+\Delta S^{*}{ }_{a} / 2.303 R\right]$. The analysis of the results was 
obtained in Table 6, from Table note that rise in the $\mathrm{E}_{a}^{*}$ by improving the dose of synthetic compound. This increase is due to the adsorption synthetic compound on the CS surface and corresponds to the physical adsorption of the synthetic compounds. The results in Table 6 also showed that entropy values are negative in the existence of synthetic compounds and these negative values showed that the activated complex in the ratedetermining step prefers association rather than dissociation step [43].

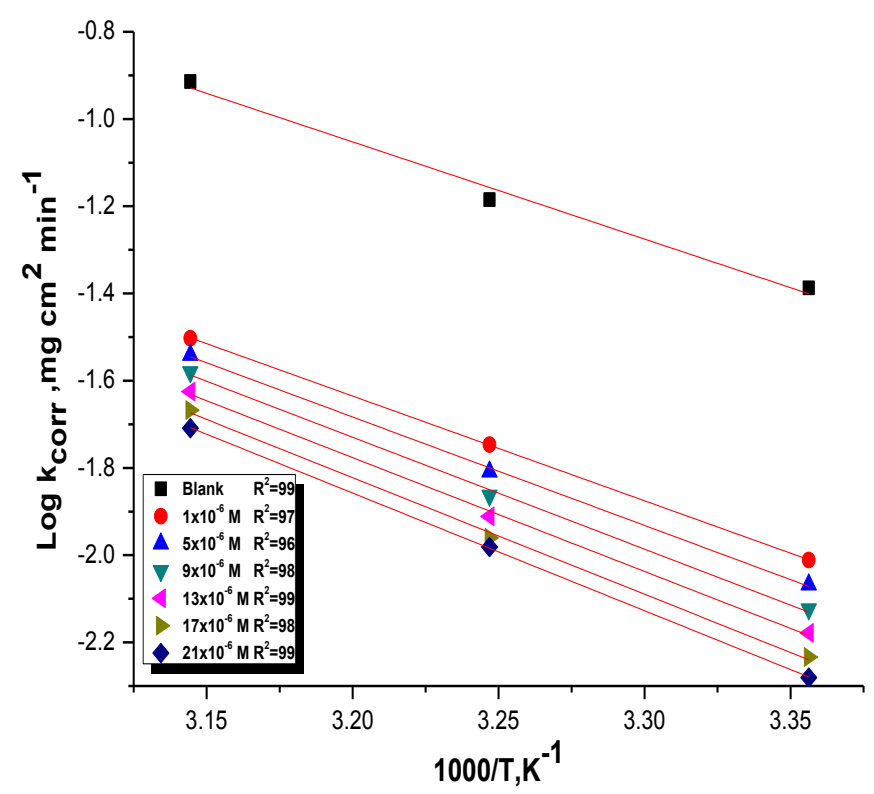

Figure 8. Plots (log $k_{\text {corr }}$ vs. 1/ T) for the dissolution of CS with and without altered doses of compound SCP2

Slika 8. Krive (log $k_{\text {corr }}$ vs. 1/T) za rastvaranje CS sa i bez izmenjenih doza jedinjenja SCP2

Table 6. Thermodynamic parameters of Arrhenius equation and transition state equation

Tabela 6. Termodinamički parametri Arrenijusove jednačine i jednačine prelaznog stanja

\begin{tabular}{|c|c|c|c|c|}
\hline \multirow{3}{*}{ Inhibitor } & \multirow{3}{*}{ Conc., $\times 10^{6} \mathrm{M}$} & \multicolumn{3}{|c|}{ Activation parameters } \\
\hline & & $\mathrm{E}_{\mathrm{a}}^{*}$ & $\Delta \mathrm{H}^{*}$ & $-\Delta S^{*}$ \\
\hline & & $\mathrm{kJ} \mathrm{mol}^{-1}$ & $\mathrm{~kJ} \mathrm{~mol}^{-1}$ & $\mathrm{~J} \mathrm{~mol}^{-1} \mathrm{~K}^{-1}$ \\
\hline blank & 0.0 & 42.64 & 40.23 & 137 \\
\hline \multirow{6}{*}{ SCP2 } & 1 & 45.96 & 43.57 & 135 \\
\hline & 5 & 47.58 & 45.19 & 133 \\
\hline & 9 & 49.10 & 46.72 & 129 \\
\hline & 13 & 49.95 & 47.57 & 127 \\
\hline & 17 & 51.13 & 48.76 & 124 \\
\hline & 21 & 51.64 & 49.27 & 123 \\
\hline \multirow{6}{*}{ SCP1 } & 1 & 44.37 & 41.97 & 141 \\
\hline & 5 & 45.49 & 43.09 & 138 \\
\hline & 9 & 47.35 & 44.96 & 133 \\
\hline & 13 & 48.34 & 45.96 & 130 \\
\hline & 17 & 49.32 & 46.94 & 127 \\
\hline & 21 & 51.17 & 48.81 & 122 \\
\hline
\end{tabular}




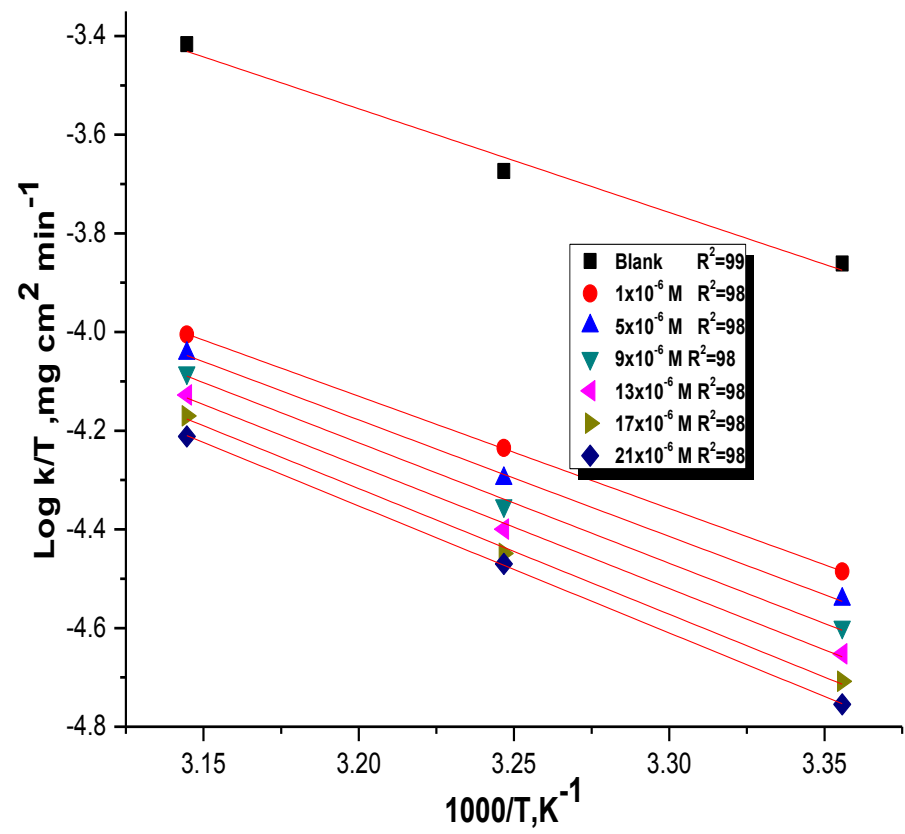

Figure 9. Plots of (log $\left.k_{\text {corr }} / T\right)$ vs. 1/T for the dissolution of CS with and without altered doses of compound SCP1

Slika 9. Krive (log $\left.k_{c o r r} / T\right)$ vs. 1/T za rastvaranje CS sa i bez izmenjenih doza jedinjenja SCP1

\subsection{Electrochemical Measurements}

\subsubsection{Potentiodynamic Polarization (PP) Technique}

PP test is carrying out in $1.0 \mathrm{M}$ hydrochloric medium with and without altered doses of synthetic compounds at $25^{\circ} \mathrm{C}$. The outcome data are collected in Table 7 . The following parameters were obtained: electrochemical corrosion [i $\left.\mathrm{i}_{\text {corr }}\right]$, corrosion potential $\left(\mathrm{E}_{\text {corr }}\right)$, and cathodic and Tafel anode constants $\left(\beta_{c}\right.$ and $\left.\beta_{a}\right)$. Figure 10 depicts the polarisation curves in the absence and presence of synthetic SCP2, SCP1, and it was discovered that the presence of inhibitors causes changes in the polarisation behaviour of CS and pushes cathodic curves to lower current densities when compared to those in pure acid solution. The inclusion of these chemicals reduces the corrosion potential to more negative values while maintaining the anodic domain current density nearly unchanged. This finding implies that the presence of these chemicals inhibits solely the cathodic reaction of hydrogen evolution while having no effect on the anodic dissolution of the CS. According to the results in Table 7, the presence of various dosages of synthetic compounds produces a decrease in current density with increasing doses of these compounds, as well as the formation of a layer on the CS surface. Furthermore, the data of the cathode and anode Tafel slopes show no significant change in the presence of different synthetic chemical dosages (Figure 10). This can be explained by the fact that the corrosion process is caused by covering the active sites located on the surface of the CS. This indicates a dissolution mechanism that is not affected by the presence of synthetic compounds. If the change in corrosion potential $\left(E_{\text {corr }}\right)$ values is greater than $\pm 85 \mathrm{mV}$ in the presence and absence of synthetic molecule, the inhibitor molecules are classified as cathodic or anodic type, and this did not happen because the corrosion potential values displacement less than $\pm 85 \mathrm{mV}$. The corrosion current density diminished with increasing the doses of the synthetic compounds but the small change of the $E_{\text {corr }}$ (63 $\mathrm{mV})$ and the slightly change of $\left(\beta_{\mathrm{a}} \& \beta_{\mathrm{c}}\right)$ on rising the doses of the utilized inhibitors, this revealed that these compounds act as mixed type inhibitors $[44,45]$. The $\left(\eta_{\text {Tafel }} \%\right)$ was calculated from PP curves as follows:

$$
\eta_{\text {Tafel }} \%=\left[1-\left(i_{\text {corr }} / i_{\text {corr }}^{o}\right)\right] \times 100
$$

where $\mathrm{i}_{\text {corr }}^{\mathrm{O}}$ and $\mathrm{i}_{\text {corr }}$ correspond to the uninhibited and inhibited corrosion current densities, correspondingly and determined by extrapolation of both Tafel lines to the corrosion potential. 
Table 7. Parameters attained from PP technique for the corrosion of CS in the absence and presence of altered doses of synthetic compounds (SCP1 \& SCP2) at $25^{\circ} \mathrm{C}$

Tabela 7. Parametri dobijeni PP tehnikom za koroziju CS u odsustvu i prisustvu izmenjenih doza sintetičkih jedinjenja (SCP1 i SCP2) na $25^{\circ} \mathrm{C}$

\begin{tabular}{|c|c|c|c|c|c|c|c|c|}
\hline Comp & $\begin{array}{l}\text { Conc.x } \\
10^{-6} \mathrm{M}\end{array}$ & $\begin{array}{c}\mathrm{i}_{\text {corr, }} \\
\mu \mathrm{A} \mathrm{cm}^{-2}\end{array}$ & $\begin{array}{c}-E_{\text {corr, }} \\
m V \text { vs SCE }\end{array}$ & $\begin{array}{c}\beta_{a} \\
m V \operatorname{dec}^{-1}\end{array}$ & $\begin{array}{c}-\beta_{\mathrm{c}} \\
\mathrm{mV} \mathrm{dec}^{-1}\end{array}$ & $\begin{array}{l}\text { C.R } \\
\text { mpy }\end{array}$ & $\theta$ & $\% n$ \\
\hline \multirow{6}{*}{ SCP2 } & 1 & 125.0 & 420 & 118 & 173 & 65 & 0.747 & 74.7 \\
\hline & 5 & 112.0 & 423 & 116 & 186 & 51 & 0.773 & 77.3 \\
\hline & 9 & 88.0 & 422 & 120 & 196 & 41 & 0.822 & 82.2 \\
\hline & 13 & 69.0 & 425 & 123 & 184 & 38 & 0.860 & 86.0 \\
\hline & 17 & 58.0 & 420 & 122 & 181 & 31 & 0.883 & 88.3 \\
\hline & 21 & 48.0 & 425 & 121 & 187 & 29 & 0.903 & 90.3 \\
\hline \multirow{6}{*}{ SCP1 } & 1 & 134.0 & 426 & 110 & 163 & 71 & 0.729 & 72.9 \\
\hline & 5 & 121.0 & 423 & 123 & 176 & 53 & 0.755 & 75.5 \\
\hline & 9 & 97.0 & 421 & 118 & 186 & 49 & 0.804 & 80.4 \\
\hline & 13 & 78.0 & 425 & 118 & 174 & 43 & 0.842 & 84.2 \\
\hline & 17 & 63.0 & 422 & 115 & 181 & 37 & 0.872 & 87.2 \\
\hline & 21 & 50.0 & 420 & 116 & 177 & 32 & 0.899 & 89.9 \\
\hline
\end{tabular}
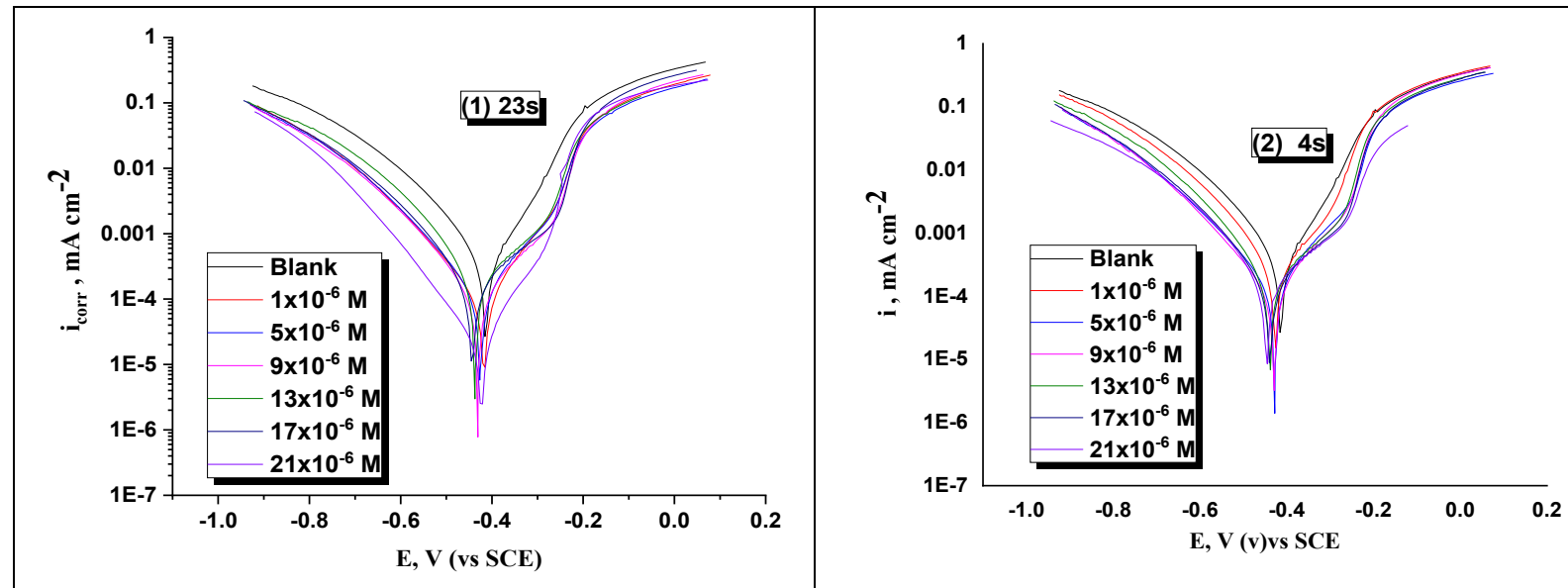

Figure 10. PP curves for the dissolution of CS in the absence and presence of altered doses of synthetic compounds (SCP1 \& SCP2) at $25^{\circ} \mathrm{C}$

Slika 10. PP krive za rastvaranje CS u odsustvu i prisustvu izmenjenih doza sintetičkih jedinjenja (SCP1 $i$ SCP2) na $25^{\circ} \mathrm{C}$

\subsubsection{Electrochemical Impedance Spectroscopy (EIS) Technique}

EIS test were carried out at $25^{\circ} \mathrm{C}$ in acid medium with and without synthetic inhibitors. Figure 11 shows the impedance values of the CS resulting from equivalent circuit tests when there are altered doses of synthetic compounds. In this circuit, constant phase elements (CPE) are used as a substitute for capacitors to provide multiple types of homogenizations that are not ideal for electrode corrosion, such as grain boundaries, surface impurities and roughness, a lower in polishing. From the following equation the capacitance double layer $\left(\mathrm{C}_{\mathrm{dl}}\right)$ was designed:

$$
C_{d l}=\left(1 / 2 \pi f . R_{c t}\right)
$$

Table 8 displays the findings obtained from impedance data for CS in $0.1 \mathrm{M}$ hydrochloric acid 
in the presence and absence of changed synthetic component dosages. The charts produced by [Nyquist and Bode] for CS in the absence and presence of various dosages of the synthetic chemicals employed are presented in Figs $(11,12)$. According to the Nyquist plot in Figure 11, the radius of the circle grows as the dosage of the synthetic chemical increases, as does the charge transfer resistance (Rct) in corrosion processes. According to the current findings, high resistance has been created as a result of synthetic chemical adsorption at the CS -solution/interface [46]. The divergence of the Nyquist curves from semicircles is caused by the CS surface heterogeneity and frequency dispersion [47]. According to Figure 11, all of the Nyquist plots have a single incomplete semicircle, which corresponds to one time constant in the Bode plots. This indicates that the corrosion of $\mathrm{CS}$ in $\mathrm{HCl}$ solution was regulated by a single charge transfer mechanism, and the addition of inhibitors to the system had no effect [48].

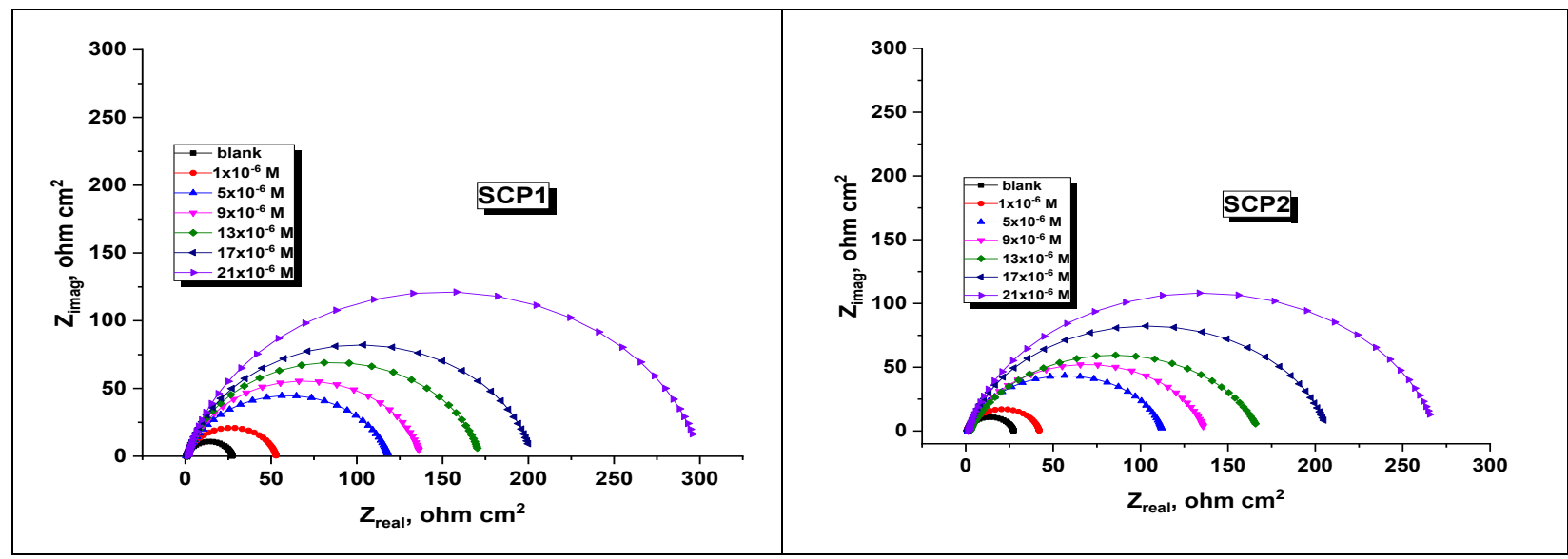

Figure 11. The Nyquist plots for CS dissolution in 1.0M HCl with and without altered doses of SCP2 and SCP1 at $25^{\circ} \mathrm{C}$

Slika 11. Nyquist-ovi dijagrami za rastvaranje CS u 1,0M HCl sa i bez izmenjenih doza SCP2 i SCP1 na $25^{\circ} \mathrm{C}$

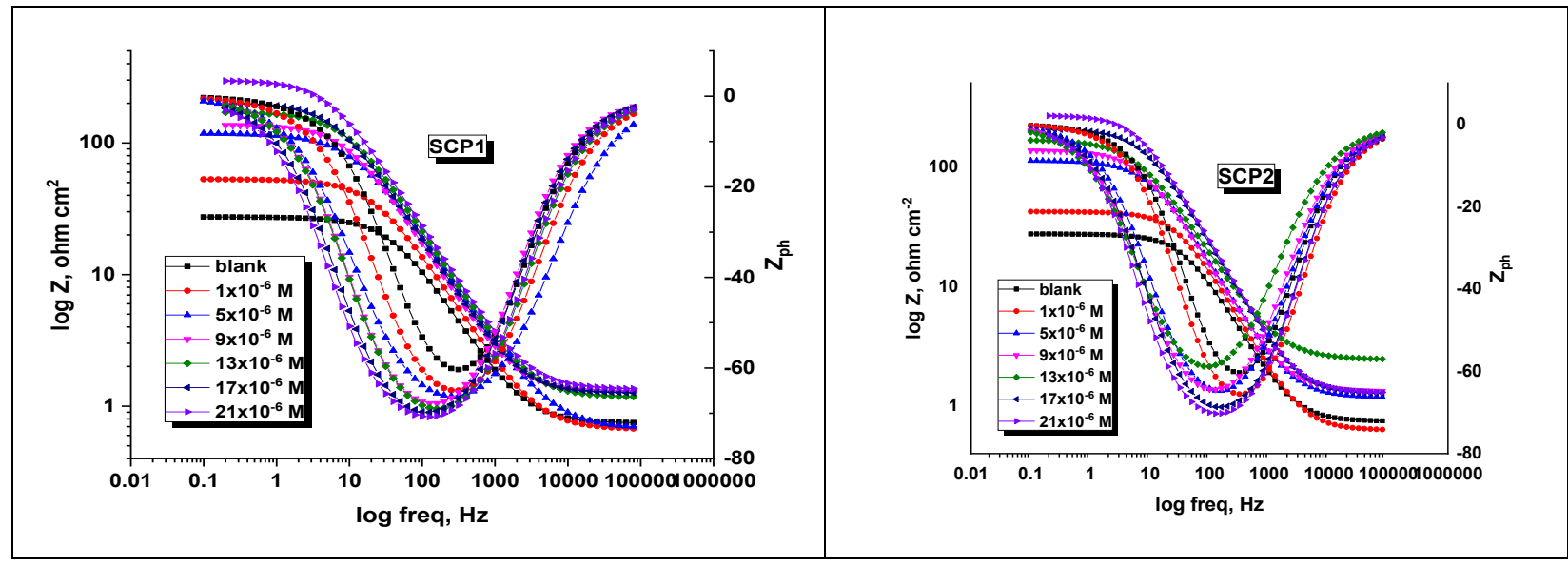

Figure 12. The Bode plots for CS dissolution in 1.0M HCl with and without altered doses of SCP2 and SCP1 at $25^{\circ} \mathrm{C}$

Slika 12. Bode-ovi dijagrami za rastvaranje CS u $1,0 \mathrm{M} \mathrm{HCl}$ sa i bez izmenjenih doza SCP2 i SCP1 na $25^{\circ} \mathrm{C}$

When compared to the free acid, the value of Bode plots and phase angles increased in Figure 12. This might be attributed to inhibitor molecule adsorption at the metal surface [49]. Table 8 shows a decrease in Cdl data as the dose of synthetic chemical increases, which may be explained by a decrease in the local dielectric constant and/or an increase in the thickness of the 
electrical double layer [50]. This is related to the adsorption of synthetic chemical molecules on the CS/solution interface." Table 8 shows a decrease in Cdl data as the dose of synthetic chemical increases, which may be explained by a decrease in the local dielectric constant and/or an increase in the thickness of the electrical double layer [51]. This is due to the adsorption of synthetic chemical molecules on the CS/solution interface."The Table also shows that $(n)$ values fluctuate directly with the inhibitor dosage. $(n)$ value is a measure of surface roughness [52], and its rise in our case might imply a reduction in the heterogeneity of the CS surface due to inhibitor adsorption.EIS parameters and $\% \eta$ were calculated from eqn. (10):

$$
\% \eta=\left(1-R_{c t} / R_{c t}^{0}\right) \times 100
$$

Where $\mathrm{R}_{\mathrm{ct}}$ and $R_{c t}{ }^{\circ}$ are the charge-transfer resistances the inhibited and uninhibited values, correspondingly.

It is noted that the profile of all the plots with and without inhibitors are similar and again support the assertion from PP and ML studies that addition of inhibitors did not actually change the mechanism of CS dissolution in the studied environment. Equivalent circuit models shown in Figure 13 are used to simulate obtained impedance data. Equivalent circuit models shown in Figure 13 are used to simulate obtained impedance data.

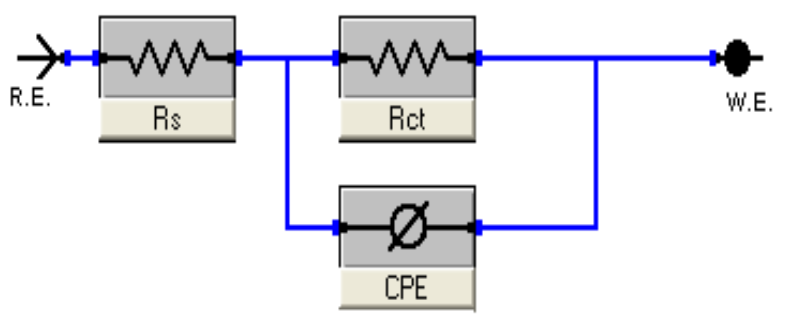

Figure 13. Equivalent circuit utilized to fit the impedance data

Slika 13. Ekvivalentno kolo koje se koristi za uklapanje podataka o impedansi

Table 8. Parameters of EIS for dissolution of CS in $1.0 \mathrm{M} \mathrm{HCl}$ with and without altered doses of synthetic compounds (SCP2 and SCP1)

Tabela 8. Parametri EIS-a za rastvaranje CS u 1,0 MHCl sa i bez izmenjenih doza sintetičkih jedinjenja (SCP2 i SCP1)

\begin{tabular}{|l|c|c|c|c|c|c|}
\hline Comp & Conc., $\times 10^{6} \mathrm{M}$ & $\mathrm{R}_{\mathrm{ct}}, \Omega \mathrm{cm}^{2}$ & $\mathrm{C}_{\mathrm{dl}}, \mu \mathrm{Fcm}$ & $\mathrm{n}$ & $\theta$ & $\% \eta$ \\
\hline Blank & 0 & 27 & 165 & 0.824 & ---- & ---- \\
\hline \multirow{5}{*}{ SCP2 } & 1 & 68 & 136 & 0.844 & 0.608 & 60.8 \\
\cline { 2 - 7 } & 5 & 110 & 124 & 0.863 & 0.758 & 75.8 \\
\cline { 2 - 7 } & 9 & 136 & 122 & 0.871 & 0.804 & 80.4 \\
\cline { 2 - 7 } & 13 & 161 & 118 & 0.880 & 0.834 & 83.4 \\
\cline { 2 - 7 } & 17 & 187 & 109 & 0.884 & 0.857 & 85.7 \\
\hline \multirow{5}{*}{ SCP1 } & 21 & 269 & 102 & 0.886 & 0.901 & 90.1 \\
\cline { 2 - 7 } & 1 & 55 & 148 & 0.923 & 0.515 & 51.5 \\
\cline { 2 - 7 } & 5 & 104 & 136 & 0.934 & 0.744 & 74.4 \\
\cline { 2 - 7 } & 9 & 128 & 129 & 0.941 & 0.792 & 79.2 \\
\cline { 2 - 7 } & 13 & 155 & 121 & 0.943 & 0.828 & 82.8 \\
\cline { 2 - 7 } & 17 & 181 & 113 & 0.944 & 0.853 & 85.3 \\
\hline
\end{tabular}

\subsubsection{Electrochemical Frequency Modulation (EFM) Technique}

EFM is characterized by speed and greatly accuracy in calculating the current data [53]. Figure 14 , indicates the EFM of $\mathrm{CS}$ in $1.0 \mathrm{M} \mathrm{HCl}$ solution and altered doses of synthetic SCP1 Similar curves were obtained for another SCP (not shown). The EFM parameters such as (CF-2 and CF-3), ( $\beta_{\mathrm{c}}$ and $\beta_{a}$ ) and ( $\left.i_{\text {corr }}\right)$ can be measured from the higher current peaks. The CF is closer to the standard data proved the validity of the calculated data $[54,55]$. The $\% \eta$ increases with the raising of synthetic compound and was calculated and listed Table 9. The data presented in Table 9, by increasing concentration of synthetic compound, the current density has a noticeable decrease, and hence $\% \eta$ increased. Using this technique, the following was extracted: With an increased dose of 
synthetic compounds, there is a noticeable lowered in the intensity of the corrosion current and a clear increase in the $\% \eta$. The calculated $\% \eta$ obtained from WL, PP and EIS methods are in best agreement with that obtained from EFM test.
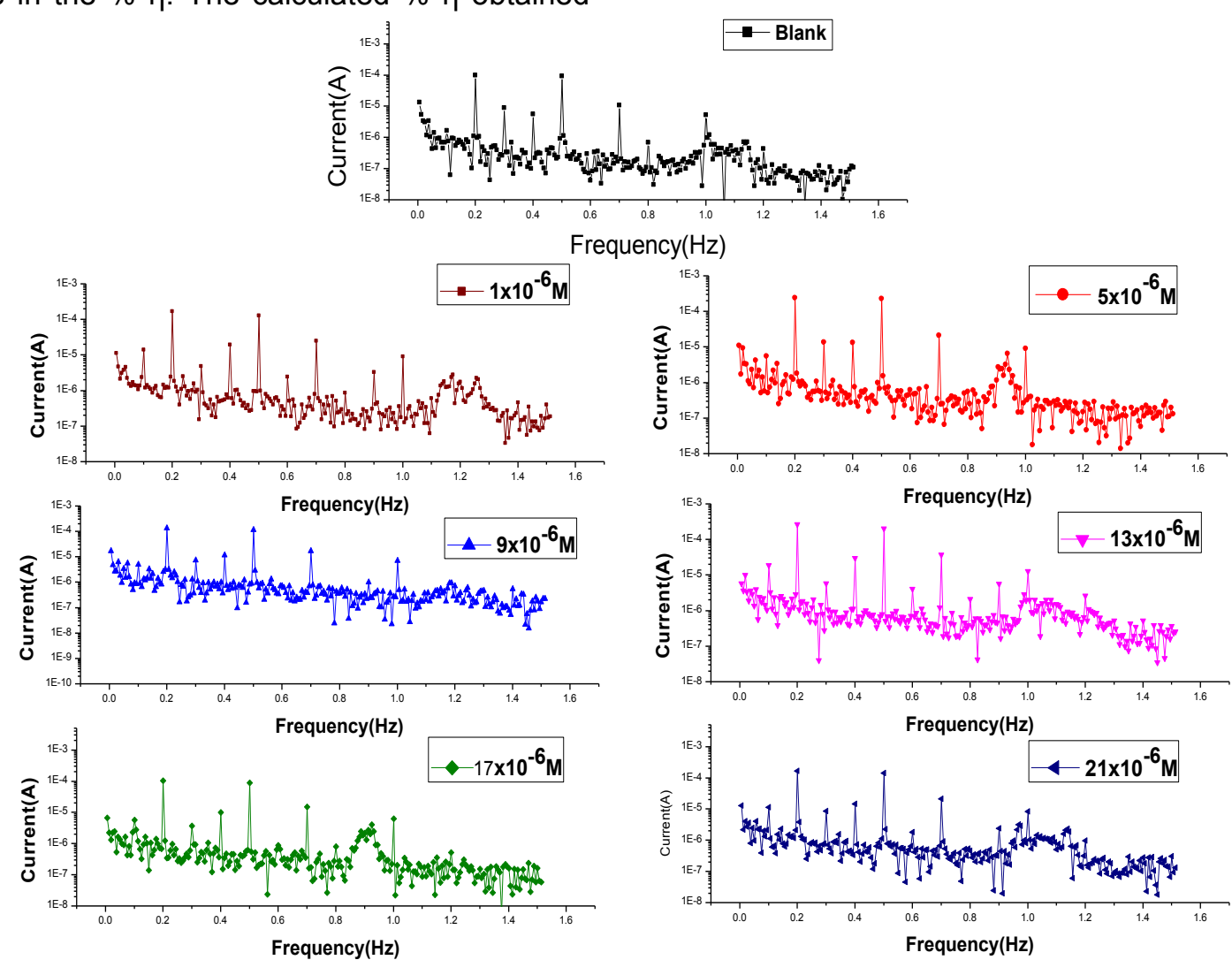

Figure 14. EFM spectra for CS dissolution in 1.0M HCl with and without altered doses of synthetic compound SCP1 at $25^{\circ} \mathrm{C}$

Slika 14. EFM spektri za rastvaranje CS 1,0M HCl sa i bez izmenjenih doza sintetičkog jedinjenja SCP1 na $25^{\circ} \mathrm{C}$

Table 9. EFM data for CS dissolution in 1.0M HCl with and without altered doses of synthetic compounds (SCP2 \& SCP1)

Tabela 9. EFM podaci za rastvaranje CS u 1,0M HCl sa i bez izmenjenih doza sintetičkih jedinjenja (SCP2 \& SCP1)

\begin{tabular}{|c|c|c|c|c|c|c|c|c|c|}
\hline Comp & Conc. $\times 10^{-6} \mathrm{M}$ & $\mathrm{i}_{\text {corr }} \mu \mathrm{Acm}^{-2}$ & $\beta_{a}, \mathrm{mVdec}^{-1}$ & $\beta_{\mathrm{c}}, \mathrm{mVdec}^{-1}$ & C.R, mpy & CF-2 & CF-3 & $\theta$ & $\%$ IE \\
\hline Blank & 0.0 & 543 & 125 & 153 & 255 & 1.8 & 3.1 & ------ & ---- \\
\hline \multirow{6}{*}{ SCP2 } & 1 & 222 & 123 & 144 & 120 & 2.0 & 3.1 & 0.591 & 59.1 \\
\hline & 5 & 168 & 118 & 159 & 105 & 1.9 & 3.1 & 0.691 & 69.1 \\
\hline & 9 & 138 & 115 & 154 & 87 & 2.0 & 2.8 & 0.746 & 74.6 \\
\hline & 13 & 93 & 113 & 149 & 65 & 1.9 & 2.9 & 0.829 & 82.9 \\
\hline & 17 & 79 & 116 & 139 & 44 & 1.8 & 3.0 & 0.855 & 85.5 \\
\hline & 21 & 56 & 120 & 144 & 34 & 2.0 & 2.9 & 0.897 & 89.7 \\
\hline \multirow{6}{*}{ SCP1 } & 1 & 252 & 122 & 144 & 129 & 2.0 & 2.9 & 0.536 & 53.6 \\
\hline & 5 & 186 & 113 & 159 & 110 & 1.9 & 3.1 & 0.657 & 65.7 \\
\hline & 9 & 151 & 110 & 154 & 95 & 1.9 & 2.8 & 0.722 & 72.2 \\
\hline & 13 & 108 & 111 & 149 & 77 & 2.1 & 3.0 & 0.801 & 80.1 \\
\hline & 17 & 83 & 120 & 139 & 75 & 2.0 & 2.9 & 0.847 & 84.7 \\
\hline & 21 & 61 & 118 & 144 & 48 & 1.9 & 3.0 & 0.888 & 88.8 \\
\hline
\end{tabular}




\subsection{Mechanism of Corrosion Inhibition}

The adsorption figure is known to be affected by numerous factors, the most important of which are: "the chemical composition of the solution, the nature of the CS surface, and the electrochemical potential at the CS / solution interface." Bonding, chemical adsorption, and physical adsorption are the three primary forms of adsorption that may occur. In general, if the inhibitor compounds contain heteroatoms such as nitrogen, sulphur, and oxygen, these atoms may protonate in acid medium, resulting in electrostatic adsorption of these protonated molecules on the CS surface (which is recharged by negative charge due to the adsorption of $\mathrm{Cl}^{-}$ions on it), forming an insoluble layer that reduces the dissolution of the metal. The inhibitive properties of such synthetic compounds depend on the electron densities around the active centers The inhibitory effects of such synthetic substances are determined by the electron densities surrounding the active centres." The two compounds yielded nearly identical percentages, while compound (1) yielded a pitifully low percentage. The polar effect [56] can explain for this order of decreasing percentage of synthetic additives. This might be because compound SCP2 has a larger molecular size than compound SCP1, and the presence of $\mathrm{O}$ and $\mathrm{N}$ atoms, as well as the presence of a benzene ring.

\section{CONCLUSIONS}

The investigated synthetic compounds $(1,2)$ display good performance as corrosion inhibitors for $\mathrm{CS}$ in $\mathrm{HCl}$ solution. Polarization research displayed that these synthetic compounds perform as mixed type inhibitors for $\mathrm{CS}$ in $\mathrm{HCl}$ solution. Impedance data designated that $\mathrm{R}_{\mathrm{ct}}$ data raised, while $\mathrm{C}_{\mathrm{dl}}$ data depressed in the presence of the synthetic inhibitors. The adsorption of these compounds had recognized to follow the Henry isotherm signifying that the inhibition process happens via adsorption. The $\% \eta$ achieved from ML, PP, EIS and EFM are in excellent agreement.

\section{REFERENCES}

[1] J. Kruger (1986) Corrosion of metal: An overview in M.B Bever (ed), ency. of materials science and engineering, vol 2.

[2] V.Garcia-Arriaga, J.Alvarez-Ramirez, M.Amaya, E.Sosa (2010) $\mathrm{H}_{2} \mathrm{~S}$ and $\mathrm{O}_{2}$ influence on the corrosion of carbon steel immersed in a solution containing $3 \mathrm{M}$ diethanolamine, Corros. Sci., 52, 2268-2279.

[3] D.Jayaperumal (2010) Effects of alcohol-based inhibitors on corrosion of mild steel in hydrochloric acid, Mater Chem Phys, 119, 478-484.
[4] B.Malinovic, T.Djuricic, D.Zoric (2020) Corrosion behaviour of stainless steel EN 1.4301 in acid media in presence of PBTCA inhibitor, Zastita Materijala, 61(2), 133-140.

[5] A.M.Al-Sabagh, M.M.Osman, A.M.Omar, I.M.ElGamal (1996) Organic corrosion inhibitors for steel pipelines in oilfields, Anti-Corrosion Methods and Materials, 43, 11-16

[6] B.N.Grgur (2020) Corrosion of the stainless steel $316 \mathrm{Ti}$ in $10 \%$ hydrochloric and sulfuric acid, Zastita Materijala, 61(4), 339-346.

[7] B.A.Abd-El-Naby, O.A.Abdullatef, E.Khamis, W.A.El-Mahmody (2016) Effect of Cetyltrimethyl ammonium bromide Surfactant as Novel Inhibitor for the Corrosion of Steel in $0.5 \mathrm{M} \mathrm{H}_{2} \mathrm{SO}_{4}$, Int. J. Electrochem. Sci.,11, $1271-1281$.

[8] X.H.Li, S.D.Deng, H. Fu, G.N.Mu (2009) Synergistic Inhibition Effect of Red Tetrazolium and Uracil on the Corrosion of Cold Rolled Steel in $\mathrm{H}_{3} \mathrm{PO}_{4}$ Solution: Weight Loss, Electrochemical, and AFM Approaches, Mater.Chem.Phys.,115, 815-824.

[9] A. El-Aziz S. Fouda, S. A. Abd El-Maksoud, S. A. Abd El-Salam (2017) Mitigation of corrosion of carbon steel in acid medium using some antipyrine derivatives, Zastita materijala, 58(1), 5-17.

[10] R.H.Tammam, A.M.Fekry, M.M.Saleh (2016) Understanding Different Inhibition Actions of Surfactants for Mild Steel Corrosion in Acid Solution Int. J. Electrochem. Sci.,11, 1310 - 1326.

[11] D.P.Schweinsberg, V.Ashworth (1988) The inhibition of the corrosion of pure iron in $0.5 \mathrm{M}$ sulphuric acid by n-alkyl quaternary ammonium iodides, Corros Sci, 28, 539-548.

[12] A.S.Fouda, H.Ibrahim, S.Rashwan, A.El-Hossiany, R.M.Ahmed (2018) Expired Drug (pantoprazole sodium) as a Corrosion Inhibitor for High Carbon Steel in Hydrochloric Acid Solution, Int. J. Electrochem. Sci., 13,6327-6346.

[13] M.A.Migahed, M.Abd-El-Raouf, A.M.Al-Sabagh, H.M.Abd-El-Bary (2005) Effectiveness of some nonionic surfactants as corrosion inhibitors for carbon steel pipelines in oil fields, Electrochim Acta, 50, 4638-4689.

[14] V.R.Saliyan, A.V.Adhikari (2008) Inhibition of corrosion of mild steel in acid media by $\mathrm{N}^{\prime}$ benzylidene-3-(quinolin-4-ylthio) propanohydrazide, Bull. Mater. Sci., 31, 699-711.

[15] A.S. Fouda, S.A.Abd El-Maksoud, A.El-Hossiany, A.Ibrahim (2019) Corrosion Protection of Stainless Steel 201 in Acidic Media using Novel Hydrazine Derivatives as Corrosion Inhibitors, Int. J. Electrochem. Sci., 14, 2187-2207.

[16] M.N.Shalaby, M.M.Osman (2009) Protection of copper surface against corrosion by cationic surfactant in seawater., J Disp Sci Tech, 30, 677683.

[17] A.El-Aziz S.Fouda, Ay.Y.El-Khateeb, N. M.Elbahrawi (2017) Cupressus sempervirens extract as green inhibitor for corrosion of carbon steel in hydrochloric acid solutions, Zastita Materijala, 60(2), 129-146. 
[18] A.El-Aziz S. Fouda, A.H. Ali (2018) Egy- dronate drug as promising corrosion inhibitor of $\mathrm{C}$ - steel in aqueous medium, Zastita Materijala, 59(1), 126140.

[19] A.S.Fouda, K.Shalabi, A.El-Hossiany (2016) Moxifloxacin Antibiotic as Green Corrosion Inhibitor for Carbon Steel in $1 \mathrm{M} \mathrm{HCl}$, J. Bio Tribo-Corros., 2,18- 26.

[20] S. Rajendran, M. Agasta, R.B. Devi, B.S. Devi, K. Rajam, J. Jeyasundari (2009) Corrosion inhibition by an aqueous extract of Henna leaves (Lawsonia Inermis L), Zastita Materijala, 50(1), 77-84.

[21] H. M. Elabbasy, S. M. Zidan, Abd El-Aziz S. Fouda (2019) Inhibitive behavior of ambrosia maritima extract as an eco-friendly corrosion inhibitor for carbon steel in $1 \mathrm{M} \mathrm{HCl}$, Zastita Materijala, 59(1) 126-140.

[22] A.Frignani, V.Grassi, F.Zanotto, Zucchi (2012) Inhibition of AZ31 Mg alloy corrosion by anionic surfactants, Corros. Sci., 63, 29-39.

[23] Y.Di, Y.Zongxue, C.Legang and C.Kunyao (2019) Enhancement of the Anti-Corrosion Performance of Composite Epoxy Coatings in Presence of BTA loaded Copper-Based Metal-Organic Frameworks, Int. J. Electrochem. Sci., 14, 4240-4253.

[24] S.Kumaraguru, R.Pavulraj and S.Mohan (2017) Influence of $\mathrm{Co}, \mathrm{Ni}$, Cu-based MOFs on the corrosion protection of mild steel, Int. J. Surf. Eng. Coat., 95(3), 131-136.

[25] J. Nakomčić, Đ. Vaštag (2016) Derivati tiazola i triazol kao inhibitori korozije metala, I deo, Zastita materijala, 57(2), 183-195.

[26] S.E.H.Etaiw, A.S.Fouda (2011) Structure, Characterization and Anti-Corrosion Activity of the New Metal-Organic Framework [Ag(qox)(4-ab)], J. Inorg. Organomet. Pol. Mat., 21, 327- 335.

[27] A.S.Fouda, S.E.H.Etaiw (2016) MOFs based on silver(I) and $\mathrm{N}$-donors as new corrosion inhibitors for $\mathrm{Cu}$ in $\mathrm{HCl}$ solutions, J. Mol. Liq., 213, 228-234.

[28] Z.Sakinch, N.S. Mahdi and G.Mahboube (2020) New MOF based corrosion inhibitor for carbon steel in acidic media, Met. Mater., Int., 26, 25-38.

[29] F.B.Stocker, D.Britton, V.G.Young (2000) Crysta Structures of a Family of Silver Cyanide Complexes of Thiourea and Substituted Thioureas, J. Inorg. Chem., 39, 3479-3484.

[30] S.E.H.Etaiw, A.S.Badr Edin (2011) Supramolecular Design of Coordination Polymers Based on Silver (I) Azide and Nitrogen Donor Ligands, J. Inorg. Organomet. Polym., 21, 1-8.

[31] T.J.Mooibroek, G.Arom, M.Quesada, O.Roubeau, P.Gamez, S.D.George (2009) Slageren J.V., Yasin S., Ruiz E., Reedijk J., A Mixed-Valent Pentanuclear (Cull4Cul) Compound Containing a Radical-Anion Ligand, Inorg. Chem., 48, 1064310651.

[32] K.F.Khaled (2009) Evaluation of electrochemical frequency modulation as a new technique for monitoring corrosion and corrosion inhibition of carbon steel in perchloric acid using hydrazine carbodithioic acid derivatives, J. Appl. Electrochem., $39,429-438$
[33] D.A.Jones (1983) Principles and Prevention of Corrosion, second ed., Prentice Hall, Upper Saddle River, NJ, USA.

[34] R.J.Williams, A.C.Larson, D.T.Cromer (1972) The crystal structure of the mixed valence copper cyanide ethylenediamine complex: aquobis

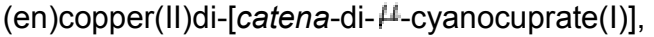
$\mathrm{Cu}_{3}(\mathrm{en})_{2}(\mathrm{CN})_{4} \cdot \mathrm{H}_{2} \mathrm{O}$, Acta Cryst. B, 28, 858-864

[35] S.E.H.Etaiw, S.N.Abdou, A.S.Badr Eldin (2015) Structure and spectral characterization of coordination polymers constructed by $\mathrm{Cu} C N$ and aliphatic diamines, J Inorg Organomet Polym., 25, 1394-1406.

[36] Gamry Echem Analyst Manual (2003).

[37] N.O.Eddy, E.E.Ebenso (2010) Adsorption and quantum chemical studies on cloxacillin and halides for the corrosion of mild steel in acidic media, Int. J. Electrochem. Sci., 5, 731-750.

[38] A.S.Fouda, M.Abdel Azeem, S.A.Mohamed, A.ElHossiany (2019) El-Desouky E., Corrosion Inhibition and Adsorption Behavior of Nerium Oleander Extract on Carbon Steel in Hydrochloric Acid Solution, Int. J. Electrochem. Sci., 14, 3932-3948.

[39] E.Kamis, F.Bellucci, R.M.Latanision, E.S.El-Ashry (1991) Acid corrosion inhibition by 2(triphenosphoranylidene)succinic anhydride. Corrosion, 47, 677-686.

[40] M.A.Amin, S.S.Abd El-Rehim, M.M.El-Naggar, H.T.Abd El-Fattah (2009) Adsorption, and corrosion inhibitive properties of some tripodal pyrazolic compounds on mild steel in hydrochloric acid systems, J. Mater. Sci., 44, 6258-6272.

[41] A.S.Fouda, A.El-Hossiany, H.Ramadan (2017) Calotrpics procera plant extract as green corrosion inhibitor for 304 stainless steels in hydrochloric acid solution, Zastita Materijala, 58(4), 541-555.

[42] E.Sokolova Popova, S.Raicheva, M.Christov (2003) $A C$ and DC study of the temperature effect on mil A.d steel corrosion in acid media in the presence of benzimidazole derivatives, Corros. Sci., 45, 33-58.

[43] A.S.Fouda, H.A.Mostafa, G.Y.Elewady, M.A.ElHashemy (2008) Low molecular weight straight chain diamines as corrosion inhibitors for ss in $\mathrm{HCl}$ solution. chemical engineering communications, 195(8), 934-947.

[44] M.Kendig, S.Jeanjaquet (2002) $\quad \mathrm{Cr}(\mathrm{VI}) \quad \mathrm{Ce}(\mathrm{III})$ inhibition of oxygen reduction on copper., J. Electrochem. Soc., 149, B47-B51.

[45] M.E.Nicho, H.Hu, J.G.Gonzalez-Rodriguez, V.M. Salinas (2006) Protection of stainless steel by polyaniline films against corrosion in aqueous environments, J. Appl. Electrochem.,36(2), 153-160.

[46] E.McCafferty, N.Hackerman (1972) double layer capacitance and corrosion inhibition with polymethylene diamines, J. Electrochem. Soc., 119, 146-154.

[47] Y.Sasikumar, A.S.Adekunle, L.O.Olasunkanmi (2015) Experimental, quantum chemical and Monte Carlo simulation studies on the corrosion inhibition of some alkyl imidazolium ionic liquids containing tetrafluoroborate anion on mild steel in acidic medium, J. Mol. Liq., 211, 105-118. 
[48] E.Kowsari, M.Payami, R.Amini (2014) Task-specific ionic liquid as a new green inhibitor of mild steel corrosion, Appl. Surf. Sci., 289, 478-486.

[49] H.Shin, H.Mansfeld (1989) A fitting procedure for impedance data of systems with very low corrosion rates, Corros.Sci., 29, 1235-1240.

[50] S.Martinez, M.Metikos-Hukovic (2003) A nonlinear kinetic model introduced for the corrosion inhibitive properties of some organic compound. J. Appl. Electrochem., 33, 1137-1142.

[51] R.W.Bosch, J.Hubrecht, W.F.Bogaerts, B.C.Syrett (2001) A new electrochemical technique for online corrosion monitoring, Corrosion, 57, 60-70.

[52] K.F.Khaled (2008) Molecular simulation, quantum chemical calculations and electrochemical studies for inhibition of steel by triazoles, Electrochim. Acta, 53, 3484-3492.
[53] K.F.Khaled (2008) New synthesized guanidine derivative as a green corrosion inhibitor for mild steel, Int. J. Electrochem. Sci., 3, 462-475.

[54] D.A.Jones (1983) Principles and Prevention of Corrosion, second ed., Prentice Hall, Upper Saddle River, NJ, USA.

[55] D.P.Schweinsberg, G.A.George, A.K.Nanayakkara, D.A.Steinert (1988) The protective action of epoxy resins and curing agents-inhibitive effects on the aqueous acid corrosion of iron and steel, Corros. Sci., 28, 33-42.

[56] A.S.Fouda, M.Abdallah, Z.El-Badrawy (2011) Some hydrazone derivatives as corrosion inhibitors for iron in $3.5 \% \mathrm{H}_{3} \mathrm{PO}_{4}$ solution, Afri. J. Pure Appl. Chem., 5(8), 24-36.

\title{
IZVOD
}

\section{SINTEZA DVA SUPRAMOLEKULARNA KOORDINACIONA POLIMERA I ELEKTROHEMIJSKA PROCENA NJIHOVOG UČINKA INHIBICIJE KOROZIJE NA KOROZIJU UGLJENIČNOG ČELIKA U KISELOJ SREDINI}

\begin{abstract}
Efekat SCPs-[Cu"(en $\left.)_{2}\right]\left[\mathrm{Cu}^{\prime}(\mathrm{CN})_{2}\right]_{2} . \mathrm{H}_{2} \mathrm{O}(\mathrm{SCP} 1)$ i $\left\{\left[\mathrm{H}_{2} \mathrm{DAB}\right]\left[\mathrm{Cu}_{4}(\mathrm{CN})_{6}\right] .2 \mathrm{H}_{2} \mathrm{O}\right\}$ (SCP2) kao inhibitori korozije za ugljenični čelik (CS) proučavani su u $1,0 \mathrm{M}$ rastvoru $\mathrm{HCl}$. Kako se doza sintetizovanog inhibitora povećava, produktivnost inhibicije (\%n) raste dostižući 90,3\% i 89,9\% pri dozi od $21 \times 10^{-6} \mathrm{M}$ za SCP2 i SCP1, respektivno. Ovaj rezultat je dokazan gubitkom mase (ML) ispitivanim na tri različitih temperatura $25-35-45^{\circ} \mathrm{C}$, dok su potenciodinamička polarizacija (PP), spektroskopija elektrohemijske impedanse (EIS) i tehnika elektrohemijske modulacije frekvencije (EFM) testirani na $25^{\circ} \mathrm{C}$. Sintetizovani inhibitori adsorbovani na površini CS fizički dozvoljavajući Henrijevu izotermu. Rezultati su pokazali da su sintetisani inhibitori odlični i da je njihov (\% $)$ značajno povećan povećanjem doze i smanjen povećanjem temperature. Polarizacione krive su pokazale da sintetisani inhibitori deluju kao mešoviti tip. Termodinamički parametri su izračunati $i$ diskutovani. Zaštita je potvrđena stvaranjem tankog filma inhibitora taloženog na površini CS.
\end{abstract}

Ključne reči: Supramolekularni koordinacioni polimeri, kisela korozija, ugljenični čelik, Henrijeva izoterma, EIS.

Naučni rad

Rad primljen: 03. 08. 2021.

Rad korigovan: 27. 09. 2021.

Rad prihvaćen: 06. 10. 2021.

Rad je dostupan na sajtu: www.idk.org.rs/casopis

(C) 2021 Authors. Published by Engineering Society for Corrosion. This article is an open access article distributed under the terms and conditions of the Creative Commons Attribution 4.0 International license (https://creativecommons.org/licenses/by/4.0/) 